\title{
Estimating Structural Models of Equilibrium and Cognitive Hierarchy Thinking in the Field: The Case of Withheld Movie Critic Reviews*
}

\author{
Alexander L. Brown ${ }^{\dagger}$ \\ Texas A\&M University \\ Colin F. Camerer \\ California Institute of Technology \\ Dan Lovallo \\ The University of Sydney
}

March 18, 2012

\begin{abstract}
Film studios occasionally withhold movies from critics before their release. Since the unreviewed movies tend to be below average in quality, this practice provides a useful setting in which to test models of limited strategic thinking: Do moviegoers seem to realize that no review is a sign of low quality? A companion paper showed that in a set of all widely released movies 2000-09, cold opening produces a significant 20-30\% increase in domestic box office revenue, which is consistent with moviegoers overestimating quality of unreviewed movies (perhaps due to limited strategic thinking). This paper reviews those findings and provides two models to analyze this data, an equilibrium model and a behavioral cognitive hierarchy $(\mathrm{CH})$ model that allows for differing levels of strategic thinking between moviegoers and movie studios. The behavioral model fits the data better, as moviegoer parameters are relatively close to those observed in experimental subjects. These results suggests that limited strategic thinking may be a better explanation for naïve moviegoer behavior than equilibrium reasoning is.
\end{abstract}

${ }^{*}$ Thanks to audiences at Caltech, Chicago GSB, Berkeley, Yale Graduate Student Conference on Behavioral Science, 2007 North American ESA, SJDM, SEA, 2010 AEA meetings and the 8th Triennial Invitational Miami Choice Symposium, especially Stefano Della Vigna, David Grether, Stuart McDonald, Tom Palfrey, Charles Plott, Robert Sherman, and Leeat Yariv. Thanks to Esther Hwang, Carmina Clarke, Ferdinand Dubin, Zachary Bethune, Cheng Cheng, Xinrong Li and Jonathan Garrity for help with data collection. Thanks to Matt Shum and the Bush School Empirical Workshop, especially Stephanie Houghton, Steve Puller and Lori Taylor, for help during revision. This paper has benefitted from the very helpful comments of the editor and three referees.

${ }^{\dagger}$ Corresponding author. Please contact at abrown@econmail.tamu.edu. 


\section{Introduction}

Game theory has sometimes been criticized as a descriptive model of business practice, or a source of normative advice, on the grounds that most analysis assumes people forecast accurately what others will do, and choose best responses given their accurate (equilibrium) forecasts. Recently, models have been developed which allow plausible limits on strategic thinking. These models are particularly useful because their basic principles can apply to many different games. One class of models that has been applied to many data sets is a "cognitive hierarchy" $(\mathrm{CH})$ model of levels of steps of thinking (and its close relative, level- $k$ ). These models have been used to explain normal form games in a wide variety of experimental ${ }^{1}$ and field settings ${ }^{2}$ but the only applications of these theories to games with private information so far are analyses of auctions. ${ }^{3}$ This paper explores the generality of these approaches through the first field application of models of limited strategic thinking to games with private information. ${ }^{4}$

The setting we study is Hollywood movies. Movie studios generally show movies to critics well in advance of the release (so that critics' reviews can be published or posted before the movie is shown, and can be quoted in newspaper ads). However, movies are often deliberately made

\footnotetext{
${ }^{1}$ See Nagel (1995), Stahl and Wilson (1995), Camerer et al. (2004), Crawford and Iriberri (2007a); Crawford et al. (2010)

${ }^{2}$ Goldfarb and Yang (2009), apply these models to firm adoption of 56K modems, Goldfarb and Xiao (in press) study strategic entry of phone companies into new markets and Östling et al., (2011) use Swedish lottery choices and experimental analogues.

${ }^{3}$ See Crawford and Iriberri (2007b) and Wang (2006).

${ }^{4}$ This setting is one example of a more general class of disclosure games in which a seller who knows something about a product's quality can choose whether to disclose a signal of its quality or not (see Verrecchia (2001, section 3) and Fishman and Hagerty (2003) for surveys). These disclosure games have been extensively studied in economics (see Dranove and Jin, 2010, for an exhaustive listing), but this paper is the first to tie the process of disclosure to models of limited strategic thinking and estimate them structurally. This paper examines the disclosure process, testing strategic disclosure as a response of producers to the limited strategic thinking of consumers.
} 
unavailable to film critics in advance of their initial release, a practice sometimes called "cold opening." If moviegoers believe that studios know their movie's quality (and if some other simplifying assumptions hold, see Brown et al., in press), then rational moviegoers should infer that cold opened movies are below average in quality.

Anticipating this accurate negative inference by moviegoers, studios should only cold open the very worst movies. However, this conclusion requires many steps of iterated reasoning (and many simplifying assumptions). So it is an empirical question whether the equilibrium prediction fits behavior. If it does not fit well, it is also an empirical question whether neoclassical explanations can explain the data or whether models of limited strategic thinking, initially designed to explain experimental data as well or better than neoclassical models, fit the studios' cold-opening decisions.

A fully rational analysis of simple disclosure games, due originally to Grossman (1981) and Milgrom (1981), implies that cold opening should not be profitable if some simple assumptions are met. The argument can be illustrated numerically with a simple example. Suppose movie quality is uniformly distributed from 0 to 100 , moviegoers and studios agree on quality, and firm profits increase in quality. If studios cold open all movies with quality below a cutoff 50, moviegoers with rational expectations will infer that the expected quality of a cold opened movie is 25 . But then it would pay to screen all movies with qualities between 26 and 100, and only cold open movies with qualities 25 or below. More generally, if the studios do not screen movies with qualities below $q^{*}$, the consumers' conditional expectation if a movie if unscreened is $q^{*} / 2$, so it pays to screen movies with qualities $q \in\left(q^{*} / 2,100\right]$ rather than just $q \in\left(q^{*}, 100\right]$. The logical conclusion of iterating this reasoning is that only the worst movies (quality 0) are unscreened. This conclusion 
is sometimes called "unravelling." 5 We proceed with the maintained hypothesis that complete unravelling should occur in theory, if studios and consumers are perfectly rational.

The $\mathrm{CH}$ models also proceed through the steps of strategic thinking in the rational unravelling argument, except that they assume that some fraction of moviegoers end their inference process after a small number of steps. For example, a 0-level moviegoer thinks that cold opening decisions are random (they convey no information about quality) and hence infers that the quality of a coldopened movie is average. A 1-level studio anticipates that moviegoers think this way and therefore opens all below-average movies cold, and shows all above-average movies to critics. Higherlevel thinkers iterate more steps in this process. Observed behavior will then be an average of the predicted behaviors at each of these levels weighted by the fraction of moviegoers and studios who do various numbers of steps of thinking. (More details of this model are given in section 3).

The data generally do not agree with the standard full disclosure model. Roughly $10 \%$ of the movies in our sample are opened cold (though that fraction has increased sharply in recent years). Regressions show that cold opening appears to generate a box office premium (compared to similar-quality movies that are pre-reviewed, and including many other controls). Since box office returns are strongly correlated with subjective quality (measured by either critic or fan ratings), the cold opening premium suggests fans think the movie is better than it actually is. We also conclude that this explanation is consistent with four of five stylized facts in this environment, none of which can be explained by a neoclassical model. ${ }^{6}$

\footnotetext{
${ }^{5}$ In the most similar theoretical work, Fishman and Hagerty (2003) do provide a model of a disclosure process with both informed and uninformed consumers, although it does not specifically address limited strategic thinking.

${ }^{6}$ For example an important observation is that fan ratings of quality are correlated with critic ratings, but are systematically lower for cold-opened movies. This is consistent with the hypothesis that fans choose movies based on expected quality, and are disappointed more often in cold-opened movies (presumably because their expectations were too high).
} 
We then fit a baseline Nash Equilibrium model, similar to Seim (2006), in which studios coldopen movies when they receive a private idiosyncratic error, and a model using $\mathrm{CH}$, that can be augmented to allow disequilibrium using two separate $\mathrm{CH}$ parameters for moviegoers and studios. $^{7}$ Both baseline and $\mathrm{CH}$ models have roughly similar estimates for studio choices, since cold-openings are quite rare as predicted by equilibrium and $\mathrm{CH}$ models with high levels of thinking (there is less data with actual cold-opening box office to fit the model). However, the baseline model cannot predict cold-opening premiums from moviegoer choice while the $\mathrm{CH}$ model can.

The estimates for moviegoers thinking in the CH model, especially in the period 2000-2005, are roughly consistent with experimentally observed data. Studios in the later period (2006-2009) also have lower estimates of perceived steps-of-thinking, suggesting they may be learning to best respond to moviegoers' limited rationality.

The paper is organized as follows: Section 2 discusses data on quality ratings, box-office returns, and control variables, and presents some regression results on the existence of a box-office premium for movies that are cold opened. Section 3 describes the Bayesian-Nash and $\mathrm{CH}$ models. Section 4 estimates parameters of those models based on studios' decisions and the box office revenue. Section 5 concludes and discusses future extensions to management-related research.

\section{Data}

Much of the data and details of regression conclusions are reported in a companion paper (Brown et al., in press) so we will summarize those results which are relevant to the analysis of this paper.

\footnotetext{
${ }^{7}$ The mismatch between the degree of strategic thinking of moviegoers and studios is not typically observed in experimental data. However, keep in mind that experiments rarely use mixtures of populations which are more and less strategically sophisticated, so it is perhaps not surprising that the estimate of studio strategic thinking is very high, and is much higher than the moviegoer estimates.
} 
In much of the analysis we will make a distinction between movies from 2000-2005 and 20062009, a distinction that was not made in the companion paper.

The data set is all 1414 movies widely released in more than 600 theaters in the US in their first weekend, over the decade from January 1, 2000 to December 31, 2009. Critic and moviegoer ratings are both used to measure quality. Metacritic.com normalizes and averages ratings from over 30 movie critics from newspapers, magazines, and websites. These have a roughly normal distribution between 0 and 100. For estimation purposes, we use the percentile score of those ratings so that they are standardized to a uniform distribution between 0 and 100 . The metacritic rating is available for all non-cold-opened movies on the day they are released and is available on Monday for cold-opened movies. Because these ratings occur so early in a film's release, we assume the ratings help determine box office revenue and not vice versa (i.e., critics aren't influenced by box office). Other variables (such as, cold opening, box office revenues, movie genres and ratings, production budgets, and star power ratings) are collected from various data sources (see appendix).

Table 1 provides summary statistics for all variables. All these variables were used in a regression model to test if movies that are cold opened have significantly greater opening weekend and total US box office revenues. The table also shows separate variable means for the cold-opened movies. The cold-opened movies are somewhat statistically different in a few dimensions-they tend to be smaller in budget and theater coverage, have less well-known stars, and over-represent some genres (e.g., suspense/horror).

Each movie, $j$, has a standardized metacritic.com rating $q_{j}$, a dummy variable for whether a 


\begin{tabular}{|c|c|c|c|}
\hline variable & $\begin{array}{c}\text { mean, } \\
\text { (standard error), } \\
\text { all movies }\end{array}$ & $\begin{array}{l}\text { minimum and } \\
\text { maximum }\end{array}$ & $\begin{array}{l}\text { difference between } \\
\text { means, cold- } \\
\text { opened and } \\
\text { reviewed movies, } \\
\text { (standard error) }^{\text {a }}\end{array}$ \\
\hline $\begin{array}{l}\text { total box office revenue } \\
\text { (in millions) }\end{array}$ & $\begin{array}{l}58.501 \\
(1.806)\end{array}$ & $\begin{array}{c}0.117 \\
677.796\end{array}$ & $\begin{array}{l}-38.321^{* * \star} \\
(2.642)\end{array}$ \\
\hline $\begin{array}{l}\text { first weekend box office } \\
\text { (in millions) }\end{array}$ & $\begin{array}{l}17.961 \\
(0.507)\end{array}$ & $\begin{array}{c}0.086 \\
141.918\end{array}$ & $\begin{array}{c}-6.826^{\star * *} \\
(1.948)\end{array}$ \\
\hline metacritic rating & $\begin{array}{l}49.601 \\
(0.780)\end{array}$ & $\begin{array}{c}0.743 \\
99.845\end{array}$ & $\begin{array}{c}-31.746^{* * *} \\
(1.741)\end{array}$ \\
\hline imdb user rating & $\begin{array}{c}5.862 \\
(0.034)\end{array}$ & $\begin{array}{l}1.100 \\
8.900\end{array}$ & $\begin{array}{c}-1.472^{* * *} \\
(0.109)\end{array}$ \\
\hline theaters opened & $\begin{array}{c}2498.633 \\
(20.899)\end{array}$ & $\begin{array}{c}601.000 \\
4366.000\end{array}$ & $\begin{array}{c}-363.006^{* * *} \\
(61.008)\end{array}$ \\
\hline $\begin{array}{l}\text { production budget } \\
\text { (in millions) }\end{array}$ & $\begin{array}{l}45.871 \\
(1.094)\end{array}$ & $\begin{array}{c}0.446 \\
281.740\end{array}$ & $\begin{array}{l}-24.693^{* * *} \\
(2.161)\end{array}$ \\
\hline $\begin{array}{l}\text { advertising expenditures } \\
\text { (in millions) }\end{array}$ & $\begin{array}{l}19.007 \\
(0.259)\end{array}$ & $\begin{array}{c}0.470 \\
57.114\end{array}$ & $\begin{array}{l}-10.413^{* * *} \\
(0.480)\end{array}$ \\
\hline average competitor budget & $\begin{array}{l}42.642 \\
(0.870)\end{array}$ & $\begin{array}{c}0.000 \\
281.740\end{array}$ & $\begin{array}{l}-10.432^{\star \star *} \\
(0.000)\end{array}$ \\
\hline $\begin{array}{l}\text { average competitor advertising } \\
\text { expenditures }\end{array}$ & $\begin{array}{l}18.269 \\
(0.233)\end{array}$ & $\begin{array}{c}0.000 \\
59.076\end{array}$ & $\begin{array}{c}-3.469^{\star \star \star} \\
(0.676)\end{array}$ \\
\hline $\begin{array}{l}\text { average star ranking of lead } \\
\text { roles }^{b}\end{array}$ & $\begin{array}{c}2.125 \mathrm{E}+06 \\
(2.122 \mathrm{E}+06)\end{array}$ & $\begin{array}{c}1.500 \\
3.000 \mathrm{E}+09\end{array}$ & $\begin{array}{c}-1.472^{* * *} \\
(0.109)\end{array}$ \\
\hline $\begin{array}{l}\text { summer open } \\
\text { (1=Jun, Jul, Aug) }\end{array}$ & $\begin{array}{c}0.250 \\
(0.012)\end{array}$ & $\begin{array}{l}0.000 \\
1.000\end{array}$ & $\begin{array}{l}-0.061^{*} \\
(0.034)\end{array}$ \\
\hline $\begin{array}{l}\text { adaptation or sequel } \\
\text { (1=yes) }\end{array}$ & $\begin{array}{c}0.612 \\
(0.013)\end{array}$ & $\begin{array}{l}0.000 \\
1.000\end{array}$ & $\begin{array}{l}0.092^{* *} \\
(0.039)\end{array}$ \\
\hline $\begin{array}{l}\text { days released before Friday } \\
(1=\text { Thurs, etc. })\end{array}$ & $\begin{array}{c}0.201 \\
(0.018)\end{array}$ & $\begin{array}{r}-4.000 \\
4.000\end{array}$ & $\begin{array}{l}-0.116^{* *} \\
(0.053)\end{array}$ \\
\hline $\begin{array}{l}\text { opening weekend continues } \\
\text { after Sunday ( } 1=\text { Mon, etc.) }\end{array}$ & $\begin{array}{c}0.111 \\
(0.009)\end{array}$ & $\begin{array}{l}0.000 \\
2.000\end{array}$ & $\begin{array}{c}0.020 \\
(0.029)\end{array}$ \\
\hline $\begin{array}{l}\text { months released earlier in } \\
\text { foreign country (months) }\end{array}$ & $\begin{array}{c}0.417 \\
(0.076)\end{array}$ & $\begin{array}{c}0.000 \\
81.610\end{array}$ & $\begin{array}{c}0.002 \\
(0.220)\end{array}$ \\
\hline action or adventure (1) & $\begin{array}{c}0.149 \\
(0.009)\end{array}$ & $\begin{array}{l}0.000 \\
1.000\end{array}$ & $\begin{array}{l}-0.051^{*} \\
(0.026)\end{array}$ \\
\hline animated (1) & $\begin{array}{c}0.065 \\
(0.007)\end{array}$ & $\begin{array}{l}0.000 \\
1.000\end{array}$ & $\begin{array}{c}-0.060^{\star * \star} \\
(0.011)\end{array}$ \\
\hline comedy (1) & $\begin{array}{c}0.361 \\
(0.013)\end{array}$ & $\begin{array}{l}0.000 \\
1.000\end{array}$ & $\begin{array}{l}-0.068^{*} \\
(0.039)\end{array}$ \\
\hline documentary (1) & $\begin{array}{c}0.007 \\
(0.002)\end{array}$ & $\begin{array}{l}0.000 \\
1.000\end{array}$ & $\begin{array}{c}0.013 \\
(0.011)\end{array}$ \\
\hline fantasy or scifi (1) & $\begin{array}{c}0.069 \\
(0.007)\end{array}$ & $\begin{array}{l}0.000 \\
1.000\end{array}$ & $\begin{array}{c}0.005 \\
(0.022)\end{array}$ \\
\hline supense or horror (1) & $\begin{array}{c}0.179 \\
(0.010)\end{array}$ & $\begin{array}{l}0.000 \\
1.000\end{array}$ & $\begin{array}{c}0.304 \\
(0.040)\end{array}$ \\
\hline year of release $(2003=0)$ & $\begin{array}{c}1.670 \\
(0.076)\end{array}$ & $\begin{array}{l}-3.000 \\
6.000\end{array}$ & $\begin{array}{c}1.531^{* * *} \\
(0.220)\end{array}$ \\
\hline PG (1) & $\begin{array}{c}0.173 \\
(0.010)\end{array}$ & $\begin{array}{l}0.000 \\
1.000\end{array}$ & $\begin{array}{c}-0.127^{\text {***}} \\
(0.022)\end{array}$ \\
\hline PG-13 (1) & $\begin{array}{c}0.463 \\
(0.013)\end{array}$ & $\begin{array}{l}0.000 \\
1.000\end{array}$ & $\begin{array}{c}0.059 \\
(0.042)\end{array}$ \\
\hline$R(1)(r)$ & $\begin{array}{c}0.325 \\
(0.012)\end{array}$ & $\begin{array}{l}0.000 \\
0.000\end{array}$ & $\begin{array}{l}0.083^{* *} \\
(0.041)\end{array}$ \\
\hline observations $^{\mathrm{u}}$ & 1414 & 1414 & $163 / 1251$ \\
\hline
\end{tabular}

Table 1: Summary statistics for variables.

a. T-tests assume unequal variance. Standard error is the square root of the weighted average of sample variances.

b. For movies that do not have a second actor (e.g., a nature documentary with a narrator). The second star value is chosen arbitrarily high at 6 billion to represent the effect of no second star.

c. This value is calculated in regard to the Friday of a movie's "opening weekend." We follow the industry's classification on opening weekend, and make no decisions ourselves.

d. There are 1414 observations for all variables except 14b3 (1251 screened, 162 cold) for metacritic and 1303 (1155 screened, 136 cold) for production budget. 
movie was cold opened, $c_{j}(=1$ if cold $)$, and a vector $X_{j}$ of other variables. The model is

$$
\log y_{j}=a X_{j}+b q_{j}+d c_{j}+\epsilon_{j}
$$

where $y_{j}$ is opening weekend or total US box office for movie $j$ in 2005 dollars, standardized using the CPI index (www.bls.gov). Table 2 shows regression results on logged total box office revenue and logged opening weekend revenue, respectively.

The point of these initial regressions is not to estimate a full model with endogenous studio decisions (we will estimate such a model in section 4). Instead, the regression is simply a way of determining whether there is a difference in the revenue between cold-opened and reviewed movies. Under the standard equilibrium assumption that all quality information of cold-opened movies is inferred by logical inference of moviegoers, we should see no difference in revenues, and the cold-opening coefficient should be zero. If this is the case, it is good evidence for the Nash unravelling argument, and there is no interesting pattern for the behavioral theories to explain. The cold-opening coefficients in the first row of table 2 show, that cold opening a movie is positively correlated with the logarithm of opening weekend and total US box office revenues. ${ }^{8}$

In this paper the analysis will often be separated over the years 2000-2005 and 2006-2009. This is because the frequency of cold opening doubled in 2006 and persisted at the same level through 2009. (In financial economics it is common to break a long period into subperiods to test for robustness of effects and we adapt that method here as well.) There is no structural change in the movie industry in 2006 which justifies separating the entire sample into these two periods, but

\footnotetext{
${ }^{8}$ Note that this relationship is also found between cold opening and opening weekend and total US box office (no logarithm). So this relationship is not just a result of the functional form of the regression.
} 


\begin{tabular}{|c|c|c|c|c|c|c|}
\hline \multirow{2}{*}{$\begin{array}{l}\text { dependent variable: } \\
\text { period: }\end{array}$} & \multicolumn{3}{|c|}{ log opening weekend box office revenue } & \multicolumn{3}{|c|}{ log total box office revenue } \\
\hline & $\begin{array}{c}2000-2009 \\
\text { (1) }\end{array}$ & $\begin{array}{c}2000-2005 \\
(2)\end{array}$ & $\begin{array}{c}2006-2009 \\
\text { (3) }\end{array}$ & $\begin{array}{c}2000-2009 \\
(4)\end{array}$ & $\begin{array}{c}2000-2005 \\
(5)\end{array}$ & $\begin{array}{c}2006-2009 \\
(6)\end{array}$ \\
\hline cold opening & $\begin{array}{c}0.204^{* * *} \\
(0.057)\end{array}$ & $\begin{array}{l}0.059 \\
(0.084)\end{array}$ & $\begin{array}{c}0.301^{* * *} \\
(0.086)\end{array}$ & $\begin{array}{c}0.292^{* * *} \\
(0.064)\end{array}$ & $\begin{array}{l}0.123 \\
(0.095)\end{array}$ & $\begin{array}{c}0.386^{* * *} \\
(0.097)\end{array}$ \\
\hline metacritic rating & $\begin{array}{c}0.005^{* * *} \\
(0.001)\end{array}$ & $\begin{array}{c}0.004^{* * *} \\
(0.001)\end{array}$ & $\begin{array}{c}0.007^{* * *} \\
(0.001)\end{array}$ & $\begin{array}{c}0.005^{* * *} \\
(0.001)\end{array}$ & $\begin{array}{c}0.005^{* * *} \\
(0.001)\end{array}$ & $\begin{array}{l}0.006^{* * *} \\
(0.002)\end{array}$ \\
\hline imdb rating & $\begin{array}{c}0.010 \\
(0.020)\end{array}$ & $\begin{array}{l}0.040 \\
(0.025)\end{array}$ & $\begin{array}{l}-0.040 \\
(0.033)\end{array}$ & $\begin{array}{c}0.100^{* * *} \\
(0.022)\end{array}$ & $\begin{array}{c}0.122^{* * *} \\
(0.028)\end{array}$ & $\begin{array}{l}0.069^{*} \\
(0.037)\end{array}$ \\
\hline log theaters opened & $\begin{array}{c}1.169^{* * *} \\
(0.067)\end{array}$ & $\begin{array}{c}0.999^{* * *} \\
(0.083)\end{array}$ & $\begin{array}{l}1.273^{* * *} \\
(0.107)\end{array}$ & $\begin{array}{c}0.989^{* * *} \\
(0.075)\end{array}$ & $\begin{array}{c}0.823^{* * *} \\
(0.095)\end{array}$ & $\begin{array}{l}1.092^{* * *} \\
(0.121)\end{array}$ \\
\hline log production budget & $\begin{array}{c}0.011 \\
(0.026)\end{array}$ & $\begin{array}{l}-0.072^{\star *} \\
(0.031)\end{array}$ & $\begin{array}{l}0.103^{* *} \\
(0.042)\end{array}$ & $\begin{array}{l}0.008 \\
(0.029)\end{array}$ & $\begin{array}{l}-0.098^{* * *} \\
(0.036)\end{array}$ & $\begin{array}{l}0.127^{* * *} \\
(0.047)\end{array}$ \\
\hline $\begin{array}{l}\text { log advertising } \\
\text { expenditures }\end{array}$ & $\begin{array}{c}0.512^{* * *} \\
(0.044)\end{array}$ & $\begin{array}{c}0.630^{* * *} \\
(0.057)\end{array}$ & $\begin{array}{l}0.412^{* * *} \\
(0.067)\end{array}$ & $\begin{array}{c}0.742^{* * *} \\
(0.049)\end{array}$ & $\begin{array}{l}0.921^{* * *} \\
(0.065)\end{array}$ & $\begin{array}{l}0.595^{\star * *} \\
(0.075)\end{array}$ \\
\hline $\begin{array}{l}\text { average log competitor } \\
\text { budget }\end{array}$ & $\begin{array}{c}-0.053^{* *} \\
(0.023)\end{array}$ & $\begin{array}{l}-0.025 \\
(0.032)\end{array}$ & $\begin{array}{l}-0.061^{*} \\
(0.034)\end{array}$ & $\begin{array}{l}-0.021 \\
(0.026)\end{array}$ & $\begin{array}{l}-0.009 \\
(0.036)\end{array}$ & $\begin{array}{l}-0.017 \\
(0.038)\end{array}$ \\
\hline $\begin{array}{l}\text { average log competitor } \\
\text { advertising expenditures }\end{array}$ & $\begin{array}{l}-0.029 \\
(0.030)\end{array}$ & $\begin{array}{l}-0.076^{*} \\
(0.040)\end{array}$ & $\begin{array}{l}0.016 \\
(0.046)\end{array}$ & $\begin{array}{l}-0.033 \\
(0.034)\end{array}$ & $\begin{array}{l}-0.077^{*} \\
(0.046)\end{array}$ & $\begin{array}{c}0.011 \\
(0.051)\end{array}$ \\
\hline average log star ranking & $\begin{array}{l}-0.010^{*} \\
(0.006)\end{array}$ & $\begin{array}{c}-0.015^{* *} \\
(0.007)\end{array}$ & $\begin{array}{l}-0.026^{*} \\
(0.014)\end{array}$ & $\begin{array}{c}-0.015^{\star *} \\
(0.006)\end{array}$ & $\begin{array}{l}-0.015^{*} \\
(0.008)\end{array}$ & $\begin{array}{l}-0.026^{*} \\
(0.016)\end{array}$ \\
\hline adaptation or sequel & $\begin{array}{l}0.060^{*} \\
(0.036)\end{array}$ & $\begin{array}{l}0.157^{* * *} \\
(0.038)\end{array}$ & $\begin{array}{c}-0.313^{* * *} \\
(0.095)\end{array}$ & $\begin{array}{c}0.106^{\star * *} \\
(0.041)\end{array}$ & $\begin{array}{c}0.170^{\star * *} \\
(0.044)\end{array}$ & $\begin{array}{l}-0.196^{*} \\
(0.107)\end{array}$ \\
\hline $\begin{array}{l}\text { genre dummy variables } \\
\text { included }\end{array}$ & yes & yes & yes & yes & yes & yes \\
\hline $\begin{array}{l}\text { MPAA rating dummy } \\
\text { variables included }\end{array}$ & yes & yes & yes & yes & yes & yes \\
\hline $\begin{array}{l}\text { release date timing } \\
\text { variables included }{ }^{\text {a }}\end{array}$ & yes & yes & yes & yes & yes & yes \\
\hline observations & 1303 & 778 & 525 & 1303 & 778 & 525 \\
\hline $\mathrm{R}^{2}$ & 0.684 & 0.712 & 0.702 & 0.700 & 0.727 & 0.707 \\
\hline
\end{tabular}

Table 2: Regressions on box office revenues (in millions).

All regressions include a constant term. Tables displaying coefficients for all regressors are available in the appendix. a. Release date timing variables are "year," "days released before friday," "opening weekend continues after sunday," "months released earlier in a foreign country," and "summer open." 
there is a statistical jump in the percentage of cold openings in that year. In our first regressions, it is apparent that the cold-opening premium is greater and more significant over the later years 20062009 than the earlier years 2000-2005. However, this result could be due to the small number of cold openings in the earlier period (43 of 778 movies, about 6\%) compared to the later period (93 of 525 movies, about $18 \%$ ).

If the regression model is taken literally, these coefficients suggest that cold opening a movie increases its revenue from $6-35 \% .{ }^{9}$ However, we caution the reader in such an immediate interpretation of these results because there is no evidence that the relationship is causal. For instance, a critically-acclaimed movie with a high metacritic score would probably not make more revenue if it were cold opened. Selection of particular types of movies which benefit from cold opening is likely to be contributing to the regression results. Cold-opened movies all have metacritic scores under 67 and have a mean of 30. We do not have data for high-quality movies that are cold opened, since studios never make this choice. We account for the effect of this selection for cold opening using propensity matching in this section and later in our structural model (sections 3 and 4).

Propensity score matching techniques involve running a logistic regression to determine which other variables are the most associated with a cold-opening (see appendix) these predicted cold probabilities can be used to estimate which movies were the most likely to be cold opened. Running weighted regressions with these values, we can ignore movies that are very unlikely to be cold opened and match movies that were and were not cold opened but had similar propensities. Table 3 shows the results of three types of propensity score matching for weekend and cumulative US box office data.

\footnotetext{
${ }^{9}$ For the average gross of a cold-opened movie, $\$ 25$ million, this is roughly $\$ 1.5-8.75$ million of box office revenue.
} 


\begin{tabular}{|c|c|c|c|c|c|c|}
\hline dependent variable: & specification & $\begin{array}{l}\text { number in } \\
\text { treatment } \\
\text { group }\end{array}$ & $\begin{array}{c}\text { number in } \\
\text { control group }\end{array}$ & $\begin{array}{c}\text { average } \\
\text { treatment } \\
\text { effect on the } \\
\text { treated }\end{array}$ & $\begin{array}{l}\text { standard } \\
\text { error }\end{array}$ & t-statistic \\
\hline $\begin{array}{l}\text { log opening weekend } \\
\text { box office revenue }\end{array}$ & nearest neighbor & 138 & 76 & 0.482 & 0.178 & $2.715^{* * *}$ \\
\hline $\begin{array}{l}\text { log opening weekend } \\
\text { box office revenue }\end{array}$ & stratification & 138 & 587 & 0.404 & 0.193 & $2.093^{* *}$ \\
\hline $\begin{array}{l}\text { log opening weekend } \\
\text { box office revenue }\end{array}$ & kernel matching & 138 & 587 & 0.358 & 0.151 & $2.369^{* *}$ \\
\hline $\begin{array}{l}\text { log total box office } \\
\text { revenue }\end{array}$ & nearest neighbor & 138 & 76 & 0.530 & 0.201 & $2.645^{* * *}$ \\
\hline $\begin{array}{l}\text { log total box office } \\
\text { revenue }\end{array}$ & stratification & 138 & 587 & 0.455 & 0.190 & $2.401^{* *}$ \\
\hline $\begin{array}{l}\text { log total box office } \\
\text { revenue }\end{array}$ & kernel matching & 138 & 587 & 0.400 & 0.191 & $2.097^{* *}$ \\
\hline
\end{tabular}

Table 3: Propensity score matching results for logged US cumulative and weekend box office, 2000-2009 movies.

Cold opening is the treatment variable. A logit regression including all 23 variables and a constant (see appendix for the regression) was used to generate propensity scores. All specifications are over the area of common support. 
The propensity score matching results find that cold opening is correlated with a $35-55 \%$ positive increase in revenue for US opening weekend and cumulative box office. This result suggests a poor-quality movie could increase its revenue by one-third to one-half by cold opening. Nearest neighbor matching — a technique that matches each cold-opened movie $(j)$ with the regular released movie that has the closest propensity (to $j$ ) to have been cold opened-finds the highest positive correlation of 50\%. Other matching techniques that use more movies (596 vs. 72), but weigh each film differently, predict a lower value for the cold-opening premium (30\%-40\%). Taken together, these results suggest that the positive cold-opening premium is not a result of comparing cold-opened movies to larger, blockbuster movies that would never be cold opened, since the propensity of these large movies is low and they are ignored and receive low weight. Instead, the better differential performance of cold-opened movies compared to their equally poor quality screened-for-critics, counterparts is associated with the cold-opening premium.

However, there is further evidence to suggest the cold-opening premium was not as pronounced during 2000-2005 as it is in 2006-2009. When these propensity score matching techniques are used on the two specific periods, 2000-2005 and 2006-2009, separately, the coefficient for the cold-opening premium in the first period is insignificant (and negative in sign, see appendix). This provides more evidence of a regime shift after 2005 in the profitability of cold-opened movies, or it may be due to other factors. Nonetheless, the overall result on the profitability of cold-opened movies is strong: there is a pronounced "cold-opening" premium in the data in the entire sample, using both regression and propensity matching. 


\subsection{Five Stylized Facts about Cold Openings}

Our companion paper, Brown et al. (in press), notes five main stylized facts about cold openings that any explanation for cold-opening must explain. That paper argues that other explanations such as moviegoers not learning about reviews, angry critics and consumer-critic differences, are unlikely to explain all five facts. The box office premium could be due to an omitted variable that is correlated with the decision to cold open, a possibility which is difficult to rule out. Interviews with industry executives did not suggest any such variable. A promising candidate variable is an unusually good print ad or movie trailer that makes an awful movie look great. Studios should spend extra on marketing to promote such movies if they cold open them. However, the interaction between (demeaned) marketing budget and cold opening dummy has a negative and highly significant effect on box office in both time periods (the full-sample coefficient is $-0.276, t=-3.46$ ). Thus, unusually expensive marketing is associated with lower cold-opening box office, which is inconsistent with a "great trailer" type of omitted variable explanation.

We do not go into details of other explanations here (see Brown et al., in press). Instead we note that the standard Nash model cannot explain any of these facts, but an extended version of the $\mathrm{CH}$ model has an explanation for all five. The facts are:

1. There is an apparent correlation between cold opening and US box office revenue.

2. The correlation is very similar whether quality ratings are derived from critics (metacritic) or from fans who saw the movie (IMDB).

3. The correlation is less pronounced in non-US markets, especially the foreign language market Mexico, where releases are typically later, after US reviews are available. 


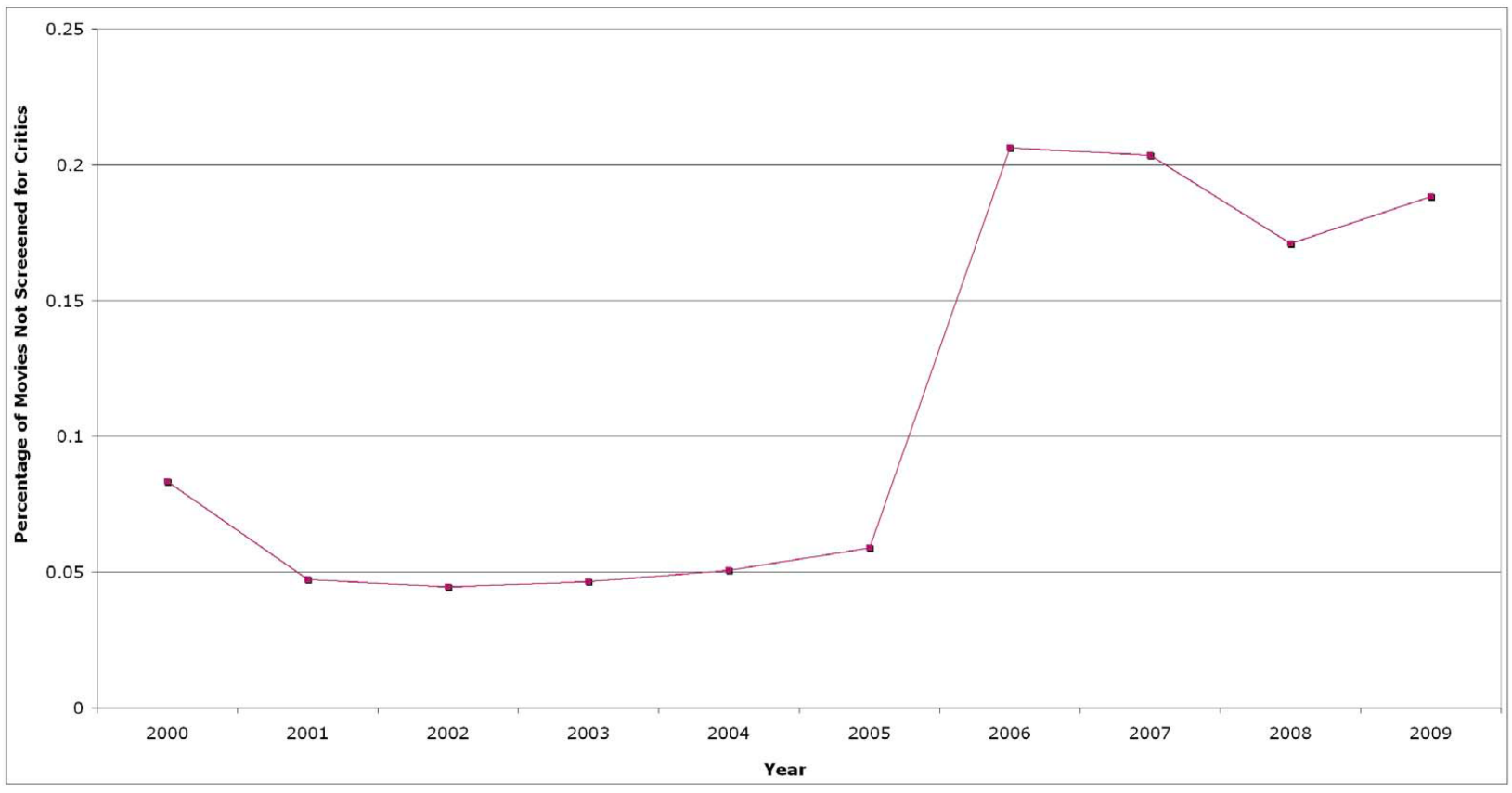

Figure 1: Percent of widely-released movies cold opened by year, 2000-2009

4. IMDB fan ratings are about 0.5 points lower (on a 10-point scale) for cold-opened movies than for comparable-quality movies that were not cold opened, suggesting fans are disappointed.

5. Cold openings are rare overall, but are increasingly frequent over the years in the sample (as shown in figure 1).

The standard neoclassical model cannot easily explain any one of these five facts. It does not predict a cold-opening premium (fact 1 and 2). It does not predict differential performance of coldopenings in other markets, since quality information should be correctly inferred in all markets (fact 3). It does not explain why cold-opened movies have lower IMDB fan ratings (fact 4). Since it predicts cold-openings should not happen, or should only happen by studio idiosyncratic error, it does not predict why they should be more frequent in the second part of the data set (fact 5).

A CH model can provide plausible explanations for the first four facts, and the conclusions of 
experiments that inspired the $\mathrm{CH}$ model can provide an explanation for fact 5. Cold-openings generate a box-office premium due to the limited strategic thinking of moviegoers in non-disclosure, as they believe cold-opened movies have higher quality than in actuality (facts 1 and 2). In foreign markets where quality information is already known, cold-openings do not have this premium as moviegoers infer quality correctly (fact 3). More moviegoers go to cold-openings than if the movie had been screened for critics, because they infer quality incorrectly, therefore the average fan rating of cold-opened movies will be lower than screened movies (fact 4$).{ }^{10}$

Fact 5 is that the rate of cold opening goes up over time. The baseline model explanation of this fact is that idiosyncratic error is going up over time, which is unlikely. However, the $\mathrm{CH}$ model does not have an immediate explanation of the rate of increase either. Keep in mind that $\mathrm{CH}$ models were initially developed to explain "pre-equilibrated" behavior in one-shot games (and to supply initial conditions for learning models). They may or may not have much explanatory power in settings like this, in which studios and moviegoers make a few decisions a year over ten years. Our explanation is that early in the sample, studios underestimated how naïve moviegoers could be (evidenced by the very high estimates of strategic sophistication in 2000-2005, see section 4 for these estimations). While moviegoers learned slowly, studios learned more quickly after noticing that cold opened movies often did fine at the box office despite no reviews (or, in the $\mathrm{CH}$ approach, because there were no reviews). This asymmetry in learning is consistent with the rise in cold openings over time, but there may well be other explanations that are not incorporated in either

\footnotetext{
${ }^{10}$ For an explanatory example, consider the moviegoer who overestimates a movie's quality based on strategic naiveté. Suppose that if he knew the movie's true quality, or knew that it was cold opened and inferred correctly its lower quality, he would not see it in theaters. This type of moviegoer is present in the audience of cold-opened movies but does not go to movies screened for critics. Thus IMDB ratings for cold-opened movies are lower, all else being equal, because these moviegoers bring down their ratings, but not for movies screened for critics. By analogy, imagine an expensive restaurant that posts a menu online but does not list prices. If the highest-priced restaurants withhold prices, and naïve diners do not infer that relation, they will always be complaining about the surprisingly expensive prices at the restaurants they go to that did not post a menu.
} 
equilibrium or $\mathrm{CH}$ models.

\section{The General Model}

The initial regressions in Section 2 were not designed to understand the endogenous choice of studios to cold open and the likely reactions of moviegoers. Instead, we create a structural model of movie viewing and studio choice where moviegoers choose whether to see a movie and studios choose whether to screen the movie for critics. Our aim is to create a model that can be analyzed with box office data and studio choice, in which each side simultaneously maximizes utility and profit respectively, but also a model that we may augment to allow estimation of parameters of limited strategic thinking concerning beliefs. To ensure that we can calculate equilibrium strategies for moviegoers and consumers this model is static. However, we will examine the model over two different time periods to account for the sudden and sustained increase in cold opening at the end of our dataset (i.e., 2000-2005 and 2006-2009, see figure 1).

Formally, let movie $j$ have characteristics $X_{j}$ that are known to the studio and moviegoers.

We assume that studios know the quality of their movie, $q_{j}$ and then choose whether to open cold $\left(c_{j}=1\right)$ or to screen for critics in advance $\left(c_{j}=0\right)$. Moviegoers do not know $q_{j}$, and form a belief $E_{m}\left(q_{j} \mid c_{j}, X_{j}\right)$ that depends on a movie's characteristics $X_{j}$ and whether it was cold opened $c_{j}{ }^{11}$

To model moviegoer utility functions and studio profit functions, we use an approach similar to Seim (2006) who examined the equilibrium entry decision in the video rental market of multiple firms. While her paper examined an equilibrium of homogenous firms, our paper examines

\footnotetext{
${ }^{11}$ It is not crucial that moviegoers literally know whether a movie has been cold-opened or not (e.g., surveys are likely to show that many moviegoers do not know). The essential assumption for analysis is that beliefs are approximately accurate for pre-reviewed movies and formed based on some different behavioral assumption for cold-opened movies.
} 
the equilibrium between moviegoers and studios who have different objective functions. ${ }^{12}$ Moviegoers form utility estimates of a given movie based upon its characteristics and expected quality, subtracting the ticket price, $\gamma$.

$$
U\left(X_{j}, E_{m}\left(q_{j} \mid c_{j}, X_{j}\right)\right)=\alpha E_{m}\left(q_{j} \mid c_{j}, X_{j}\right)+\beta X_{j}-\gamma+\epsilon_{j}
$$

The term $\epsilon_{j}$ represents moviegoers' idiosyncratic preferences over movie $j$. Similar to Seim (2006) we assume this term is private information known to the moviegoer and independently and identically distributed from a logisitic distribution (e.g., McFadden, 1974). We define the opportunity utility of not going to the movies as zero. ${ }^{13}$ The probability that the moviegoer will go to movie $j$ with characteristics $X_{j}$ and expected quality $E_{m}\left(q_{j} \mid c_{j}, X_{j}\right)$, at ticket price $\gamma^{14}$ is ${ }^{15}$

$$
\begin{aligned}
p\left(X_{j}, E_{m}\left(q_{j} \mid c_{j}, X_{j}\right)\right) & =P\left(U\left(X_{j}, E_{m}\left(q_{j} \mid c_{j}, X_{j}\right)\right)>0\right) \\
& =P\left(\epsilon_{j}>\gamma-\alpha E_{m}\left(q_{j} \mid c_{j}, X_{j}\right)-\beta X_{j}\right) \\
& =\frac{\exp \left(\alpha E_{m}\left(q_{j} \mid c_{j}, X_{j}\right)+\beta X_{j}-\gamma\right)}{\exp \left(\alpha E_{m}\left(q_{j} \mid c_{j}, X_{j}\right)+\beta X_{j}-\gamma\right)+\exp (0)} \\
& =\frac{1}{1+\exp \left(\gamma-\alpha E_{m}\left(q_{j} \mid c_{j}, X_{j}\right)-\beta X_{j}\right)}
\end{aligned}
$$

\footnotetext{
${ }^{12}$ This general approach has also been used in previous studies of limited rationality. See Goldfarb and Yang (2009) and Goldfarb and Xiao (in press), though all only studied producer behavior.

${ }^{13}$ This is without loss of generality because a constant term is included in the revenue regression, which in this model is equivalent to the estimated utility of not going to the movie.

${ }^{14}$ The term $\gamma$ is fixed at the average US ticket price in 2005, \$6.71 (recall box office revenues are in 2005 dollars).

${ }^{15}$ Note that this formalization is a single variable logit and not a multinomial one. We do not assume that a moviegoer can only go to one movie in this period. We make this decision because it is not clear whether movies crowd-out other movies at the theater or have positive spillover effects. The sign on our initial regression for the competition term (see table 2) suggests that if anything the latter explanation is more likely. Given these facts and that our estimation period is the opening weekend, and the widely-released movies usually are released no more than 4 at a time, diversified over genre, we do not find the crowding out explanation plausible enough to warrant using a multinomial logit.
} 
We use a representative-agent approach to model moviegoers. We assume $p\left(X_{j}, E_{m}\left(q_{j} \mid c_{j}, X_{j}\right)\right)$ is the total share of moviegoers that go to movie $j .{ }^{16}$ We define the constant $M$ as the maximum amount of box office revenue that could be earned in the period if every moviegoer went to a movie. Then we can define expected revenue as

$$
\bar{R}\left(c_{j}, X_{j}, q_{j}\right)=\operatorname{Mp}\left(X_{j}, E_{m}\left(q_{j} \mid c_{j}, X_{j}\right)\right)=\frac{M}{1+\exp \left(\gamma-\alpha E_{m}\left(q_{j} \mid c_{j}, X_{j}\right)-\beta X_{j}\right)} .
$$

Movie studios make decisions whether to screen movies for critics based on their expected revenues (equation (4)). Studios also have idiosyncratic error term, $v_{j}$, about the additional success of the movie if it is cold opened. As with the moviegoer error term, $v_{j}$ is private information to studios and independently and identically logistically distributed. Studios will cold open a movie if $\bar{R}\left(1, X_{j}, q_{j}\right)+v_{j}>\bar{R}\left(0, X_{j}, q_{j}\right)$. The probability that a studio will cold open movie $j$ given its characteristics, $X_{j}$, and quality, $q_{j}$ is

$$
\begin{aligned}
\pi\left(X_{j}, q_{j}\right) & =P\left[v_{j}<\bar{R}\left(0, X_{j}, q_{j}\right)-\bar{R}\left(1, X_{j}, q_{j}\right)\right] \\
& =\frac{\exp \left[\bar{R}\left(1, X_{j}, q_{j}\right)\right]}{\exp \left[\bar{R}\left(1, X_{j}, q_{j}\right)\right]+\exp \left[\left(\bar{R}\left(0, X_{j}, q_{j}\right)\right]\right.} \\
& =\frac{1}{1+\exp \left[\bar{R}\left(1, X_{j}, q_{j}\right)-\bar{R}\left(0, X_{j}, q_{j}\right)\right]} \\
& =\frac{1}{1+\exp \left[M\left[p\left(X_{j}, E_{m}\left(q_{j} \mid 1, X_{j}\right)\right)-p\left(X_{j}, E_{m}\left(q_{j} \mid 0, X_{j}\right)\right]\right]\right.}
\end{aligned}
$$

The term, $E_{m}\left(q_{j} \mid 0, X_{j}\right)$, the expected quality of a movie that is released to critics, is determined

\footnotetext{
${ }^{16}$ We choose this approach rather than aggregating $p\left(X_{j}, E_{m}\left(q_{j} \mid c_{j}, X_{j}\right)\right)$ over some $N$ to avoid arbitrarily large precision in our observations. Since box-office numbers and studio decisions will be combined in an maximum likelihood estimation process to estimate the parameters of this model jointly, we believed each observation should be counted equally. If we chose to have $N$ consumers to make up box office, we then have $N$ times more precision on our moviegoer data compared to studio data.
} 
exogenously. Because critics can write about a movie they screen as well as reveal their estimates about quality in ways that are relatively costless (i.e., internet sites, newspapers), we assume that if a movie is screened to critics, its quality is then perfectly known to moviegoers. We also assume studios are aware that critics reveal their quality. Assumption 1 states that for movies screened to critics, moviegoers have accurate perceptions of the quality of the movie, and studios have accurate perceptions about moviegoer perceived quality. ${ }^{17}$

Assumption 1. $E_{m}\left[q_{j} \mid 0, X_{j}\right]=q_{j}$.

We make also make a simplifying assumption about moviegoer perceived quality that allows our structural model to match our motivating example. Recall that in our disclosure example, we went through iterations of quality (e.g., 50, 25, 12.5) without discussing other movie characteristics $\left(X_{j}\right)$. Our models will also make this assumption.

Assumption 2. $E_{m}\left[q_{j} \mid 1, X_{j}\right]$ does not depend on $X_{j}$. That is, $E_{m}\left[q_{j} \mid 1, X_{j}\right] \equiv E_{m}\left[q_{j} \mid 1\right]$.

As Milgrom (1981) and Grossman (1981) demonstrate for all disclosure games, $E_{m}\left[q_{j} \mid 1\right]=0$ in Nash equilibrium, as the system completely unravels. ${ }^{18}$ Our estimation techniques will use maximum-likelihood estimation to estimate the parameters $\alpha$, and $\beta$ that best fit the joint system. This estimation technique is explained in detail in section 3.2.

\footnotetext{
${ }^{17}$ Quality could also be known with noise and all results would hold if moviegoers are risk-neutral.

${ }^{18}$ Alternatively, one could consider the value $E_{m}\left[q_{j} \mid 1\right]$ to be bounded on the interval $[0,100]$ in a general form of the Cursed Equilibrium model (Eyster and Rabin, 2005). We will estimate the Nash equilibrium model in this paper, and leave the alternative specification in the appendix.
} 


\subsection{A Cognitive Hierarchy Model for Moviegoers and Distributors}

The alternative structural behavioral model which originally inspired this research, the cognitive hierarchy model (Camerer et al., 2004) makes a different assumption about $E_{m}\left(q_{j} \mid 1\right)$ than the equilibrium restrictions in assumption 2. The behavioral model relaxes the assumption that moviegoers go through all the iterations of strategic thinking necessary to reach the game's Nash equilibrium and corresponding quality estimate. Similarly, distributors may best respond to moviegoers who have only done a limited number of steps of strategic thinking. The $\mathrm{CH}$ model can characterize aggregate strategic behavior with a single parameter, $\tau \cdot{ }^{19}$

The $\mathrm{CH}$ model assumes that there is a population of individuals who do varying numbers of steps of iterative strategic thinking. The parameter $\tau$ determines the distribution of steps of thinking by the one-parameter Poisson distribution

$$
P(x=n \mid \tau)=\frac{\tau^{n} e^{-\tau}}{n !}
$$

where $\tau$ is the mean number of steps of strategic thinking. To develop the model similar to our baseline, we restrict moviegoer inference of quality to not include specific movie characteristics, by revising assumption 2 .

Assumption $2^{\prime}$. For all $k, E_{m}^{k}\left[q_{j} \mid 1, X_{j}, \tau\right]$ does not depend on $X_{j}$. That is, $E_{m}^{k}\left[q_{j} \mid 1, X_{j}, \tau\right] \equiv$ $E_{m}^{k}\left[q_{j} \mid 1, \tau\right]$

\footnotetext{
${ }^{19}$ The parsimony of the single parameter specification is the reason we have chosen this approach over using a level-k model (see Stahl and Wilson, 1994; Costa-Gomes et al., 2001; Costa-Gomes and Crawford, 2006; Crawford and Iriberri, 2007a,b). Also, (Camerer et al., 2004) found that the Poisson restriction fit almost as well as models with several free parameters for different level frequencies. Given that we have only box-office data and studio decisions to cold open, we would be unable to identify the proportion of levels in the population without some type of distributional assumption. The Poisson version of $\mathrm{CH}$ does give such an assumption. Other approaches are possible.
} 
Zero-level moviegoers do not think about the studio's actions of cold opening a movie. They act as if the movie's quality is average $E_{m}^{0}\left(q_{j} \mid 1, \tau\right)=50 .{ }^{20}$ They will go to any movie with probability

$$
p\left(X_{j}, E_{m}^{0}\left(q_{j} \mid 1, \tau\right)\right)=\frac{1}{1+\exp \left[\gamma-\beta X_{j}-50 \alpha\right]}
$$

A 0 -level studio will best respond to the 0-level moviegoer. ${ }^{21}$ The 0 -level studio calculates the expected revenue from cold opening a movie as

$$
\bar{R}_{0}\left(1, X_{j}, q_{j}, \tau\right)=M p\left(X_{j}, E_{m}^{0}\left(q_{j} \mid 1, \tau\right)\right)
$$

It will therefore cold open movie $j$ with probability

$$
\begin{aligned}
\pi_{0}\left(X_{j}, q_{j}, \tau\right) & =\frac{1}{1+\exp \left[M p\left(X_{j}, q_{j}\right)-\bar{R}_{0}\left(1, X_{j}, q_{j}, \tau\right)\right]} \\
& =\frac{1}{1+\exp \left[M\left[p\left(X_{j}, q_{j}\right)-p\left(X_{j}, 50\right)\right]\right]}
\end{aligned}
$$

Proceeding inductively, for $k>0$ moviegoers will consider the expectations of all moviegoers of lower types $\left(k^{\prime}<k\right)$. They will form a conditional expectation using $\tau$ of lower level types

\footnotetext{
${ }^{20}$ Assuming that 0-level players choose randomly across possible strategies is natural in many games. However, the more appropriate, general interpretation is that 0-level players are simple, or heuristic, rather than neceessarily random. For example, in "hide-and-seek" games a natural starting point is to choose a "focal" strategy (see Crawford and Iriberri (2007a)). In auctions a natural starting point is to bid one's value (Crawford and Iriberri, 2007b). In our game, random choice by moviegoers would mean random attendance at movies. That specification of 0-level play doesn't work well because it generates far too much box office revenue. It is admittedly not ideal to have special ad hoc assumptions for different games. Eventually we expect there will be a theory of 0-level play that maps the game structure and a concept of simplicity or heuristic behavior into 0-level specifications in a parsimonious way.

${ }^{21}$ An alternate specification, more in line with the spirt of experimental work, would have 0-level studios cold-open at random. The issue with this specification is that then, both 0 and 1-level moviegoers believe cold-openings have expected quality of 50. Depending on values of $\tau$, this can lead to a pattern of two successive levels of moviegoers or studios behaving in the same way, creating an identification issue. For this reason we avoid this specification. See our working paper (Brown et al., 2009) for a specification more in line with the experimental spirit.
} 
and assume studios only cold-open movies with quality lower than that expectation (as in our motivating example). Their expectation about the quality of cold-opened movies will be the average quality of movies below that threshold. Formally,

$$
\begin{aligned}
& E_{m}^{k}\left(q_{j} \mid 1, \tau\right)=\int_{0}^{\sum_{n=0}^{k-1} P(x=n \mid \tau) E_{m}^{n}\left(q_{j} \mid 1, \tau\right)} q P(q) \mathrm{d} q / \int_{0}^{\sum_{n=0}^{k-1} P(x=n \mid \tau) E_{m}^{n}\left(q_{j} \mid 1, \tau\right)} P(q) \mathrm{d} q \\
& =\frac{1}{2} \sum_{j=0}^{k-1} P(x=n \mid \tau) E_{m}^{j}\left(q_{j} \mid 1, \tau\right)
\end{aligned}
$$

Notice that (10) fits our motivating example well. A 0-level moviegoer believes cold-opened movies have quality of 50. A 1-level moviegoer knows this fact, assumes studios will only coldopen movies below quality of 50, and given a uniform distribution of quality infers cold-opened movies have quality 25. A 2-level moviegoer averages 50 and 25 using $\tau$ and believes expected quality is half this average as studios best respond to a distribution of 0 and 1-level moviegoers. A k-level moviegoer will attend a movie using the same equation as before,

$$
p\left(X_{j}, E_{m}^{k}\left(q_{j} \mid 1, \tau\right)\right)=\frac{1}{1+\exp \left[\gamma-\beta X_{j}-E_{m}^{k}\left(q_{j} \mid 1, \tau\right) \alpha\right]}
$$

For $k>0$ a studio best responds to a distribution of $k^{\prime} \leq k$ determined by $\tau$. Their choice to cold open is also dependent on their movie's specific characteristics through expected revenue. They will calculate expected revenue using

$$
\bar{R}_{k}\left(1, X_{j}, q_{j}, \tau\right)=\frac{M}{P(x<k \mid \tau)} \sum_{n=0}^{k} P(x=n \mid \tau) p\left(X_{j}, E_{m}^{n}\left(q_{j} \mid 1, \tau\right)\right)
$$


This leads to k-level, movie-specific, probability of cold opening,

$$
\pi_{k}\left(X_{j}, q_{j}, \tau\right)=\frac{1}{1+\exp \left[M p\left(X_{j}, q_{j}\right)-\bar{R}_{k}\left(1, X_{j}, q_{j}, \tau\right)\right]} .
$$

As an example, table 4 shows values for the first ten steps of thinking for a cold-opened movie, When a Stranger Calls, when $\tau_{m}=1.638$ and 100. Moviegoers' inference is determined by (10). They make a decision whether to go to the movie from (11) which determines the proportion of moviegoers that attend. A k-level studio best responds to a distribution of moviegoers $k^{\prime} \leq k$. Since they know the quality of their movie they make a decision about whether to cold open by comparing the expected revenues given moviegoers' inferred quality (conditional on a cold open choice) and the true quality, and including an idiosyncratic error term (to model stochastic choice). Notice that the values of inferred quality are the same for all movies given the steps of thinking (they do not depend on $X_{j}$ by assumption $2^{\prime}$ ), but the proportion of moviegoers that see the movie and the cold-opening probabilities depend on $X_{j}$ so those values are unique to this movie.

\subsection{Estimation}

Before the estimation procedure is explained, a few of the numbers used in the process must be clarified. The logic of the model and our data (see section 2 and table 2) suggest that cold opening most strongly affects the first weekend's revenue (which may then affect cumulative revenue). Therefore, we use the first weekend's revenue to calibrate the models' revenue equations and studio decisions. Thus, our representation of revenue, $R\left(X_{j}, E_{m}\left(c_{j}, X_{j}\right)\right)$, will use weekend box office revenue normalized to 2005 dollars. Movie ticket prices are also in 2005 dollars. The value $M$, the maximum possible box office, is chosen as double the highest weekend gross over the set being 


\begin{tabular}{|c|c|c|c|c|c|}
\hline $\begin{array}{l}\text { moviegoers steps of } \\
\text { thinking }\end{array}$ & & $\begin{array}{l}\text { Inferred quality of When } \\
\text { a Stranger... given it is } \\
\text { opened cold, }{ }^{a} \tau_{m}=1.638\end{array}$ & $\begin{array}{l}\text { Inferred quality of When } \\
\text { a Stranger... given it is } \\
\text { opened cold, }{ }^{a} \tau_{m}=100\end{array}$ & $\begin{array}{c}\text { Proportion of types out of } \\
\text { maximum possible that } \\
\text { will attend movie, } \\
\tau_{\mathrm{m}}=1.638 \\
\end{array}$ & $\begin{array}{c}\text { Probability of studio cold } \\
\text { opening movie, knowing } \\
q_{j}=6.179,{ }^{b} \tau_{s}=1.638\end{array}$ \\
\hline & 0 & 50.0000 & 50.0000 & 0.0054 & 0.5843 \\
\hline & 1 & 25.0000 & 25.0000 & 0.0047 & 0.5339 \\
\hline & 2 & 17.2383 & 12.5000 & 0.0045 & 0.5195 \\
\hline & 3 & 14.3325 & 6.2500 & 0.0044 & 0.5143 \\
\hline & 4 & 13.2184 & 3.1250 & 0.0044 & 0.5123 \\
\hline & 5 & 12.8228 & 1.5625 & 0.0044 & 0.5116 \\
\hline & 6 & 12.6995 & 0.7813 & 0.0044 & 0.5114 \\
\hline & 7 & 12.6664 & 0.3906 & 0.0044 & 0.5113 \\
\hline & 8 & 12.6586 & 0.1953 & 0.0044 & 0.5113 \\
\hline & 9 & 12.6570 & 0.0977 & 0.0044 & 0.5113 \\
\hline 10 & & 12.6567 & 0.0488 & 0.0044 & 0.5113 \\
\hline
\end{tabular}

Table 4: Moviegoer inferred quality and predicted attendance by level of thinking for When $a$ Stranger Calls at $\tau_{m}=\tau_{s}=1.638$.

a. Inferred quality by levels of thinking is the same for all movies. By assumption, it does not depend on $X_{j}$.

b. Moviegoer attendance and probability of cold-opening do depend on $X_{j}$, so these values are specific to this movie.

evaluated. ${ }^{22}$ Movie quality, $q_{j}$ is the standardized version of the average metacritic rating used in section 2. Movie characteristics $X_{j}$ are the independent variables used in the initial regressions on weekend box office in section 2 , excluding cold opening and critic rating. The term $c_{j}$ has the same value as the cold dummy in section 2 .

We jointly estimate the parameters using box office revenue data and studio-cold-opening decisions in a maximum likelihood estimation procedure. Equation 4 which represents the expected box office revenue in our model is non-linear and requires a transformation to fit a linear model. We estimate the model equation with movie specific error term $\xi_{j}$ which is normally distributed, $N(0, \sigma)$. That is,

$$
\log \left(\frac{M}{R\left(X_{j}, E_{m}\left(c_{j}, X_{j}\right)\right)}-1\right)+\gamma=\alpha E_{m}\left(q_{j} \mid c_{j}\right)+\beta X_{j}+\xi_{j}
$$

\footnotetext{
${ }^{22}$ For $2000-2005, M=249.46$, for $2006-2009, M=283.82$.
} 
Denoting the residuals of this linear model as $e$, we have a log likelihood function,

$$
L_{m}(\alpha, \beta)=-\frac{n}{2} \log \left(2 \pi \sigma^{2}\right)+\left(-\frac{1}{2 \sigma^{2}} e^{\prime} e\right)
$$

Since $\sigma^{2}$ is unknown it will be estimated by $\frac{e^{\prime} e}{N-Q}$ where $\mathrm{N}$ is the number of movies and $\mathrm{Q}$ are the number of movie characteristics including quality. ${ }^{23}$

The log likelihood for the studio decisions is calculated using the estimated predicted probabilities of cold opening. For each set of parameter values, there is a predicted probability that a cold-opened movie would have been cold opened $\left(\pi\left(X_{j}, q_{j}\right)\right)$. Similarly, for each set of parameter values, there is a predicted probability a movie that was screened for critics would have been screened for critics $\left(1-\pi\left(X_{j}, q_{j}\right)\right)$. The studio log likelihood function is the product of these values, logged.

$$
L_{s}(\alpha, \beta)=\sum_{j \in N} \log \left(c_{j} \pi\left(X_{j}, q_{j}\right)+\left(1-c_{j}\right)\left(1-\pi\left(X_{j}, q_{j}\right)\right)\right)
$$

The partial log likelihoods are summed to form a likelihood function that incorporates both boxoffice revenue and studio decisions. Estimates for the parameters in the model are obtained by maximizing the function $L(\alpha, \beta)$ defined by equation 17 .

$$
L(\alpha, \beta)=L_{m}(\alpha, \beta)+L_{s}(\alpha, \beta)
$$

\footnotetext{
${ }^{23}$ The constant $Q=24$ for the 23 movie characteristics plus critic rating. For $2000-2005$ data $N=778$, for 2006-2009 data $N=558$.
} 
For a given set of values, $(\beta, \alpha),{ }^{24}$ are both put into (15) and (16) and logged, and then summed to get a likelihood value in equation (17). Maximum likelihood parameter estimates, $\left(\alpha^{*}, \beta^{*}\right)$ are obtained using an optimization algorithm (Nelder and Mead, 1965) that begins at the origin. Standard errors of all coefficients are obtained by 100 random bootstraps of the data set using the same algorithm. For the bootstraps the algorithm is started at the parameter estimates $\left(\alpha^{*}, \beta^{*}\right)$ instead of the origin.

The $\mathrm{CH}$ model uses the same basic maximum likelihood estimation procedure as the standard model. The difference is the addition of the parameter $\tau$. Because moviegoers and studios are different types of players with different objective functions and levels of experience, the two types of players are allowed to have differing $\tau$ parameters. Moviegoers have parameter $\tau_{m}$ and studios have parameter $\tau_{s}{ }^{25}$ This will allow us to infer whether the degree of limited thinking by both studios and moviegoers are similar (i.e., if $\tau_{m} \approx \tau_{s}$ ).

As with the standard model, we jointly estimate the parameters of the $\mathrm{CH}$ model. For a given set of values $\left(\alpha, \beta, \tau_{m}, \tau_{s}\right)$ where $\tau_{m}, \tau_{s} \geq 0, \alpha, \beta$, and $\tau_{m}$ are used to compute the expected box office of cold opened (those where $c_{j}=1$ ) movies. ${ }^{26,27}$

\footnotetext{
${ }^{24}$ An alternate baseline specification treats $E\left(q_{j} \mid 1\right)$ as a free parameter instead of setting it to 0 , see appendix for the results of that specification.

${ }^{25}$ An alternative approach would be have only one $\tau$ for moviegoer and studio behavior and jointly estimate it based on studio decisions and box office data. The trouble with approach is that because cold-opening occurs so infrequently, the number of observations that determine the studio's parameter $\tau_{s}$ are roughly ten times as great as the number of observations that determine moviegoers' behavior $\tau_{m}$. For this reason any joint estimation of this type will be highly biased toward studio behavior (which already resembles the standard model), and neglect the cold-opening premium, the primary motivation for this exercise.
}

${ }^{26}$ In all estimations, for a given parameter value $\tau$ equations (18) and (13) are approximated up to the level $k=100$. All probability for values $k>100$ was assigned to $k=100$. A $\tau$ value of 100, the upper limit, was an entire distribution of 100-level thinkers.

${ }^{27}$ To allow an identical maximum likelihood estimation procedure with the baseline model, this value is converted into a single quality dimension, $\hat{q}$, such that

$$
\bar{R}\left(0, X_{j}, \hat{q}\right)=\lim _{k \rightarrow \infty} \bar{R}_{k}\left(1, X_{j}, q_{j}, \tau_{m}\right) .
$$


The parameters $\alpha, \beta$, and $\tau_{s}$ are then used to compute the probability of each movie being cold opened using equation (13). Those values are put into equation (16) to compute the other partial log likelihood. The values are then logged and summed to give a full maximum likelihood value for the parameter values $\left(\alpha, \beta, \tau_{m}, \tau_{s}\right)$. Maximum likelihood parameter estimates, $\left(\alpha^{*}, \beta^{*}, \tau_{m}^{*}, \tau_{s}^{*}\right)$ are obtained using a Nelder-Mead optimization algorithm that begins at the origin. Standard errors of all coefficients are obtained by 100 random bootstraps of the data set using the same algorithm. For the bootstraps the algorithm is started at the parameter estimates $\left(\alpha^{*}, \beta^{*}, \tau_{m}^{*}, \tau_{s}^{*}\right)$ instead of the origin. The results of both estimations are given in the next section.

\section{Structural Estimation Results}

Table 4 presents the results of the estimation of both baseline and $\mathrm{CH}$ models separated over the periods 2000-2005 and 2006-2009. For studio choices, the baseline equilibrium model (columns 1-2) with $E_{m}\left(q_{j} \mid 1\right) \equiv 0$ predicts a general reluctance of studios to cold-open movies (only $11 \%$ in 2000-2005) but it is forced to use idiosyncratic error to explain the times studios do cold open. ${ }^{28}$ The $\mathrm{CH}$ model with best fitting $\tau_{s}=100$, the upper bound, for 2000-2005 (column 3) and $\tau_{s}=$ 5.022, for 2006-2009 (column 4) (values much higher than what is typically observed in laboratory studies) can also account for the low rate of cold openings.

The one parameter for which the models differ is, importantly, the predicted cold premium. In

Basically, $\hat{q}$ functions as the single value of expected quality that would generate the same expected revenue as the $\mathrm{CH}$ model with parameter $\tau_{m}$. This value is used for all cold opened movies, and $q_{j}$ is used for all regularly released movies, to calculate the partial $\log$ likelihood in equation (15).

\footnotetext{
${ }^{28}$ Table 4 assumes $E_{m}\left(q_{j} \mid 1\right)=0$. However, if that conditional expectation is a free parameter, the best-fitting values are 0 and 9.12 in the two time periods (see web appendix for that model). The log likelihood in the later period is -673.79 , only two points better than the restricted model, and the predicted cold premium is -.054 (.015), so the restriction $E_{m}\left(q_{j} \mid 1\right)=0$ is not producing the poor premium prediction.
} 


\begin{tabular}{|c|c|c|c|c|}
\hline \multirow{3}{*}{$\begin{array}{l}\text { dependent variable: } \\
\text { model: } \\
\text { period: }\end{array}$} & \multicolumn{4}{|c|}{ moviegoer attends movie } \\
\hline & \multicolumn{2}{|c|}{ baseline } & \multicolumn{2}{|c|}{ Cognitive Hierarchy } \\
\hline & $\begin{array}{l}2000-2005 \\
(1)\end{array}$ & $\begin{array}{c}2006-2009 \\
(2)\end{array}$ & $\begin{array}{c}2000-2005 \\
(3)\end{array}$ & $\begin{array}{c}2006-2009 \\
(4)\end{array}$ \\
\hline $\begin{array}{l}\text { moviegoer mean steps of } \\
\text { thinking }(\mathrm{T})\end{array}$ & - & - & $\begin{array}{c}1.638 \\
(9.927)\end{array}$ & $\begin{array}{c}0.000 \\
(0.000)\end{array}$ \\
\hline $\begin{array}{l}\text { studio mean steps of } \\
\text { thinking }(\mathrm{T})\end{array}$ & - & - & $\begin{array}{c}100.000^{* * *} \\
(13.229)\end{array}$ & $\begin{array}{c}5.022 \\
(9.636)\end{array}$ \\
\hline metacritic rating & $\begin{array}{l}0.008^{* * *} \\
(0.001)\end{array}$ & $\begin{array}{l}0.004^{* * *} \\
(0.000)\end{array}$ & $\begin{array}{l}0.008^{* * *} \\
(0.001)\end{array}$ & $\begin{array}{l}0.006^{* * *} \\
(0.001)\end{array}$ \\
\hline imdb rating & $\begin{array}{l}-0.023 \\
(0.027)\end{array}$ & $\begin{array}{l}-0.012 \\
(0.029)\end{array}$ & $\begin{array}{l}-0.018 \\
(0.028)\end{array}$ & $\begin{array}{l}-0.014 \\
(0.029)\end{array}$ \\
\hline log theaters opened & $\begin{array}{l}1.061^{* * *} \\
(0.100)\end{array}$ & $\begin{array}{l}1.299^{* * *} \\
(0.146)\end{array}$ & $\begin{array}{l}1.057^{* * *} \\
(0.099)\end{array}$ & $\begin{array}{l}1.284^{* * *} \\
(0.142)\end{array}$ \\
\hline log production budget & $\begin{array}{l}-0.066 * \\
(0.036)\end{array}$ & $\begin{array}{l}0.117^{* *} \\
(0.056)\end{array}$ & $\begin{array}{l}-0.065^{*} \\
(0.036)\end{array}$ & $\begin{array}{l}0.131^{* *} \\
(0.056)\end{array}$ \\
\hline $\begin{array}{l}\text { log advertising } \\
\text { expenditures }\end{array}$ & $\begin{array}{l}0.621^{* * *} \\
(0.081)\end{array}$ & $\begin{array}{l}0.406^{* * *} \\
(0.091)\end{array}$ & $\begin{array}{l}0.634^{* * *} \\
(0.083)\end{array}$ & $\begin{array}{l}0.426^{* * *} \\
(0.091)\end{array}$ \\
\hline $\begin{array}{l}\text { average log competitor } \\
\text { budget }\end{array}$ & $\begin{array}{l}-0.040 \\
(0.036)\end{array}$ & $\begin{array}{l}-0.069 * \\
(0.036)\end{array}$ & $\begin{array}{l}-0.044 \\
(0.036)\end{array}$ & $\begin{array}{l}-0.071^{*} \\
(0.036)\end{array}$ \\
\hline $\begin{array}{l}\text { average log competitor } \\
\text { advertising expenditures }\end{array}$ & $\begin{array}{l}-0.079 \\
(0.049)\end{array}$ & $\begin{array}{c}0.010 \\
(0.053)\end{array}$ & $\begin{array}{l}-0.074 \\
(0.049)\end{array}$ & $\begin{array}{c}0.019 \\
(0.054)\end{array}$ \\
\hline average log star ranking & $\begin{array}{l}-0.020^{* *} \\
(0.008)\end{array}$ & $\begin{array}{l}-0.025 \\
(0.015)\end{array}$ & $\begin{array}{l}-0.020^{* *} \\
(0.008)\end{array}$ & $\begin{array}{l}-0.026^{*} \\
(0.015)\end{array}$ \\
\hline adaptation or sequel & $\begin{array}{c}0.072 \\
(0.050)\end{array}$ & $\begin{array}{l}-0.014 \\
(0.057)\end{array}$ & $\begin{array}{l}0.157^{* * *} \\
(0.039)\end{array}$ & $\begin{array}{l}-0.332^{* \star *} \\
(0.081)\end{array}$ \\
\hline $\begin{array}{l}\text { genre dummy variables } \\
\text { included }\end{array}$ & yes & yes & yes & yes \\
\hline $\begin{array}{l}\text { MPAA rating dummy } \\
\text { variables included }\end{array}$ & yes & yes & yes & yes \\
\hline $\begin{array}{l}\text { release date timing } \\
\text { variables included }\end{array}$ & yes & yes & yes & yes \\
\hline $\begin{array}{l}\text { Average quality of cold- } \\
\text { opened movie }\end{array}$ & $\begin{array}{l}19.172^{* * *} \\
(0.837)\end{array}$ & $\begin{array}{l}29.987^{* * *} \\
(1.252)\end{array}$ & $\begin{array}{l}19.023^{* * *} \\
(0.805)\end{array}$ & $\begin{array}{c}26.205^{* * *} \\
(1.623)\end{array}$ \\
\hline $\begin{array}{l}\text { Predicted cold-opening } \\
\text { percentage }^{b}\end{array}$ & $\begin{array}{l}0.108^{* * *} \\
(0.006)\end{array}$ & $\begin{array}{l}0.179^{* * *} \\
(0.013)\end{array}$ & $\begin{array}{l}0.107^{* * *} \\
(0.005)\end{array}$ & $\begin{array}{l}0.182^{* * *} \\
(0.017)\end{array}$ \\
\hline Predicted cold premium ${ }^{c}$ & $\begin{array}{l}-0.101^{* \star *} \\
(0.014)\end{array}$ & $\begin{array}{l}-0.075^{\star \star \star} \\
(0.007)\end{array}$ & $\begin{array}{c}0.105 \\
(0.103)\end{array}$ & $\begin{array}{l}0.177^{* \star *} \\
(0.040)\end{array}$ \\
\hline observations & 778 & 525 & 778 & 525 \\
\hline log likelihood & -755.19 & -676.61 & -752.49 & -664.08 \\
\hline $\begin{array}{ll}* & \text { Significant at the } 10 \% \\
* * & \text { Significant at the } 5 \% \\
* * * & \text { Significant at the } 1 \%\end{array}$ & & & & \\
\hline
\end{tabular}

Table 5: Parameter estimates for jointly estimated baseline and $\mathrm{CH}$ models by time period, using weekend box office revenue and cold-opening decisions data.

Tables displaying coefficients for all regressors are available in the appendix. Standard errors are calculated from 100 bootstraps for each model and time period. a. Actual values: 13.47, 24.49. b. Actual values: 0.055, 0.181. c. Actual values: $0.059,0.301$. 
the baseline model movies are cold opened only due to studio idiosyncratic error, and moviegoers think their quality is 0 . This means, provided movie quality is above 0 , that those movies should make less box-office revenue than if they had been screened for critics (i.e., the predicted box office premium is negative). The baseline model's predictions reflect this effect, predicting that the average cold-opened movie should do $10.1 \%$ and $7.5 \%$ worse in 2000-2005 (column 1) and 2006-2009 (column 2), respectively. The CH model parameterizes moviegoers as relatively naïve, they do on average 1.636 (column 3) and 0.00 (column 4) steps of thinking in each of the two periods. This is equivalent to an expected quality $\left(E_{m}\left(q_{j} \mid 1\right)\right)$ of 25.313 and 50.000 , respectively. Since the cold-opened movies usually have qualities below these values, there is a positive coldopening premium of $10.5 \%$ and $17.7 \%$ in each period, as moviegoers overestimate the quality of cold-opened movies. The $\mathrm{CH}$ predictions are therefore closer to actual cold-opening premiums of $5.9 \%$ and $30.1 \%$.

It is true that the log likelihood is only slightly better for $\mathrm{CH}$ than for the baseline model. However, the only difference in fit comes from explaining a small percentage of cold openings (around 10\%) and a modest premium (around 20\%). Furthermore, the baseline model clearly misestimates the sign of the box office premium, so while the overall fit is not bad, the adequate fit comes from an idiosyncratic error explanation that gets the economics wrong. And, the difference in explanatory power does increase between $\mathrm{CH}$ and baseline from 2000-2005 to 2006-2009 as the frequency of cold openings increases (5.53\% vs. 18.1\%) (the log likelihoods are -676 and -664).

Note that because of the $E_{m}\left(q_{j} \mid 1\right)=0$ assumption, in this particular baseline model moviegoers do not have correct Bayesian expectation of cold-opened quality. Moviegoers believe coldopened movies have quality of 0 , when in fact they have average quality of 19.17 and 29.98 due to studio idiosyncratic error. However, such a model which uses these correct expectations (see 
appendix) has log likelihood values of -1150 and -828 for two respective periods, much worse than the table 4 baseline or $\mathrm{CH}$ model fits.

In general, the estimated $\tau$ values for moviegoer behavior are much closer to those observed in laboratory experiments than the studio estimates. The value 1.638 is close to other experimental estimates (generally around 1-2.5). The estimated value of 0 for 2006-2009 implies a pure naïveté, not usually found in experimental data (see Camerer et al. (2004) and Östling et al., (2011)). However, the low value may be more understandable because 0 and 1-level moviegoers behave identically (see footnote 21), so the fitted 0-level play may be capturing 0-level play as well. Studio estimates suggest Nash play in 2000-2005 (high estimated $\tau_{s}$ ) and a high number of steps of thinking in 2006-2009 (high estimated $\tau_{s}$ ). Since studio executives making the decision to cold open think a great deal about their strategy, and have experience in these decisions (i.e., they are not new to these games), their higher sophistication compared to moviegoers may make some sense. At the same time, the value of 5.02 instead of 100 in the second time period suggests studios may be learning that moviegoers are more naïve than they thought in 2000-2005.

\section{Conclusion}

This paper is the first to apply a parametrized behavioral model to a game of disclosure in the field, an example of "structural behavioral economics." We study a market in which information senders (movie studios) are strategically withholding information (the quality of their movie) from information receivers (moviegoers), by not showing movies to critics in time for reviews to be published before opening weekends. Contrary to the simple Nash equilibrium, there is a "box office premium"-cold-opened movies earn more than screened movies with similar characteristics. 
We provide two structural models to explain the environment being studied. The baseline model has moviegoers expect cold openings to have the worst possible quality, and critics to coldopen entirely though idiosyncratic error. The $\mathrm{CH}$ model with a low number of thinking steps $\tau_{m}$ to represent moviegoer naïveté, and a high $\tau_{s}$ to represent studio over-sophistication has the same general qualities of the baseline model but is also able to predict the cold-opening premium. Further, the best-fitting $\tau_{m}$ values for moviegeors, derived from box office data, are relatively similar to those observed in laboratory studies. The studio's $\tau_{s}$ are much closer to Nash levels than those observed in laboratory experiments, but the shift of values from 2000-2005 to 2006-2009 suggests that studios may be learning to better respond to relatively naïve moviegoers.

The question remains why moviegoers have become more naïve about cold-openings and appear to be regressing rather than learning. Cold openings appear to have increased in profitability in the later part of the decade, suggesting if anything consumers are inferring less about their quality than before. While factors like repeated play and reputation of studios may explain the reluctance of studios to cold-open, the continued naïveté of moviegoers is difficult for standard game-theoretic models to explain. ${ }^{29}$ One explanation we prefer, though cannot prove, concerns the population of moviegoers. A third of tickets are sold to young moviegoers (age 12-24) (MPAA, 2010). While moviegoers might learn over time that cold-opened movies are surprisingly bad, the market has overlapping generations. New, naïve moviegoers are always entering the population; there is no reason to expect rapid convergence of beliefs across such a population. Of course, this explanation is just speculation, and it is an open research topic to determine the dynamics of relatively young consumer populations.

\footnotetext{
${ }^{29}$ Economic intuition and experiments on lemons (e.g. Lynch et al., 2001) suggest consumers will ultimately infer that goods whose quality is not disclosed have low quality.
} 
This paper has connected a major area of economics and management research, models of limited strategic thinking, with a major area of economic research, games of selective disclosure. From a management perspective, companies may have some intuitions that it can be advantageous to selectively withhold bad quality information, not strictly following the equilibrium analysis of Grossman (1981) and Milgrom (1981) (see Brown et al. (2009) for examples). However, this paper begins to uncover what level of bad information should be withheld, and can help explain why. We find that in the movie industry, it appears that studios are withholding too little, although they appear to be learning quickly. While the industry studied here, major movie studios, is quite unique, the main parts of the industry—products of unknown quality and critical review-are found in other industries. Moreover, many industries involve concentrated sellers than can learn to withhold and diffuse rotating consumers that will likely have difficulty learning. This suggests our approach could be applied to other industries: models of strategic thinking could be used in any industry that involves disclosure to examine what level of disclosure is optimal for managers given the limited strategic thinking of consumers.

\section{References}

Brown, Alexander L., Colin F. Camerer, Dan Lovallo. 2009. To review or not to review? Limited strategic thinking at the movie box office. Texas A\&M University.

Brown, Alexander L., Colin F. Camerer, Dan Lovallo. in press. To review or not to review? Limited strategic thinking at the movie box office. American Economic Journal: Microeconomics.

Camerer, Colin F., Teck-Hua Ho, Juin-Kuan Chong. 2004. A cognitive hierarchy model of games. 
Quarterly Journal of Economics 119(3) 861-898.

Costa-Gomes, Miguel, Vincent P. Crawford, Bruno Broseta. 2001. Cognition and behavior in normal-form games: An experimental study. Econometrica 69(5) 1193-1235.

Costa-Gomes, Miguel A., Vincent P. Crawford. 2006. Cognition and behavior in two-person guessing games: An experimental study. The American Economic Review 96(5) 1737-1768.

Crawford, Vincent P., Miguel A. Costa-Gomes, Nagore Iriberri. 2010. Strategic thinking. University of Aberdeen Business School.

Crawford, Vincent P., Nagore Iriberri. 2007a. Fatal attraction: Salience, naivete, and sophistication in experimental "hide-and-seek" games. American Economic Review 97(5) 1731-1750.

Crawford, Vincent P., Nagore Iriberri. 2007b. Level-k auctions: Can a nonequilibrium model of strategic thinking explain the winner's curse and overbidding in private-value auctions? Econometrica 75(6) 1721-1770.

Dranove, David, Ginger Zhe Jin. 2010. Quality disclosure and certification: Theory and practice. Journal of Economic Literature 48(4) 935-63.

Eyster, Erik, Matthew Rabin. 2005. Cursed equilibrium. Econometrica 73(5) 1623-1672.

Fishman, Michael J., Kathleen M. Hagerty. 2003. Mandatory versus voluntary disclosure in markets with informed and uninformed customers. Journal of Law, Economics and Organization 19(1) 45-63.

Goldfarb, Avi, Mo Xiao. in press. Who thinks about the competition? Managerial ability and strategic entry in us local telephone markets. American Economic Review. 
Goldfarb, Avi, Botao Yang. 2009. Are all managers created equal? Journal of Marketing Research (JMR) 46(5) 612-622.

Grossman, Sanford Jay. 1981. The informational role of warranties and private disclosure about product quality. Journal of Law and Economics 24 461-83.

Lynch, Michael, Ross Miller, Charles R. Plott, Russell Porter. 2001. Product Quality, Informational Efficiency, and Regulations in Experimental Markets. Economists of the twentieth century, Edward Elgar, Cheltenham, UK ; Northampton, MA USA.

McFadden, Daniel. 1974. Conditional Logit Analysis of Qualitative Choice Behavior. Academic Press, New York.

Milgrom, Paul R. 1981. Good news and bad news: Representation theorems and applications. Bell Journal of Economics 12(2) 380-391.

MPAA. 2010. Theatrical Market Statistics.

Nagel, Rosemarie. 1995. Unraveling in guessing games: An experimental study. American Economic Review 85(5) 1313-1326.

Nelder, J. A., R. Mead. 1965. A simplex method for function minimization. The Computer Journal 7(4) 308-313.

Östling, Robert, Joseph Tao-yi Wang, Eileen Y. Chou, Colin F. Camerer. 2011. Testing game theory in the field: Swedish lupi lottery games. American Economic Journal: Microeconomics 3(3) $1-33$. 
Seim, Katja. 2006. An empirical model of firm entry with endogenous product-type choices. The RAND Journal of Economics 37(3) 619-640.

Stahl, Dale O., Paul W. Wilson. 1994. Experimental evidence on players' models of other players. Journal of Economic Behavior and Organization 25(3) 309-327.

Stahl, Dale O., Paul W. Wilson. 1995. On players' models of other players: Theory and experimental evidence. Games and Economic Behavior 10(1) 218-254.

Verrecchia, Robert E. 2001. Essays on disclosure. Journal of Accounting and Economics 32(1-3) 97-180.

Wang, Joseph T. 2006. Is last minute bidding bad? California Institute of Technology. 


\section{Appendices: Not for Publication}

\section{A Description of Variables}

To determine if a movie was cold opened $\left(c_{j}=1\right)$ we examined the dates on three or four major news publications (the Los Angeles Times, New York Times, San Francisco Chronicle, and New York Post). If the dates of reviews in any of these publications were later than the release date, we examined the reasoning behind the late reviews. A movie was classified a "cold open" if at least one source stated the movie was not screened for critics before release (in most cases, none of the available sources had advance reviews).

Weekend and total US box office data as well as total box office data for international markets for movies from January 2000-June 2006 were obtained from a FilmSource database (Nielsen EDI, www.filmsource.com). The FilmSource database also included the number of theaters that showed a movie during its first weekend, the number of days in the opening weekend, and if the movie was released before Friday (generally only for anticipated blockbusters). FilmSource also gave a description of the genre of the movie, its MPAA rating (G, PG, PG-13, R), and whether the movie was adapted from previous source material. After June 2006 these values were obtained from the pro service of IMDB.com and boxofficemojo.com. All rental numbers were obtained from these two sites.

Production budget information came from IMDB.com for most movies, and from boxofficemojo.com or the-numbers.com for those missing from IMDB.com. Budget data were available for 1313 of the 1414 movies, including 138 or the 163 cold openings $(85 \%)$.

The pro version of the IMDB.com database was used to determine the star power rating of each 
movie's stars. Each week IMDB.com determined this value by ranking the number of searches done on the IMDB.com site for every person affiliated with movies. The most searched star would have value 1 . Since there are over one million stars on IMDB.com, we took the natural logarithm of the star ranking to reduce the effect of unknown stars with very high numbers. We averaged the logged star ranking for the top two stars for each movie during its opening week.

Three other variables, competition (the average production budget of other movies released on the same opening weekend), the summer dummy variable (whether the movie was released in June, July and August) ${ }^{30}$ and the year of release variable $(2000=-3,2001=-2,2002=-1,2003=0$, $2004=1,2005=2,2006=3,2007=4,2008=5,2009=6$ ) were calculated from the previous data. ${ }^{31}$

Advertising expenditures were obtained from the ad\$ spender print resources for advertising before 2007, and from the ad\$ spender database for advertising after 2007.

CPI data was obtained for the US, Mexico and United Kingdom from the Bureau of Labor Statistics.

\section{B List of movies cold-opened movies included in our dataset}

Table A.1 provides a list of each of the 138 cold-opened movies in our dataset and date of release.

\footnotetext{
${ }^{30}$ Adding specific dummy variables for each month instead of a summer dummy generally has little effect on our regressions. The results for the 2006-2009 and all years remain unchanged. The significance for the cold term in the 2000-2005 decreases for both cumulative and weekend regression, but this may be due to the fact that there are only 43 cold openings in that period and 23 dummy variables.

${ }^{31}$ The regressions had similar results when dummy variables for year were used instead of one year variable.
} 


\begin{tabular}{|c|c|c|c|}
\hline Movie Title & $\begin{array}{l}\text { date of } \\
\text { release } \\
\text { (United } \\
\text { States) }\end{array}$ & Movie Title & $\begin{array}{l}\text { date of } \\
\text { release } \\
\text { (United } \\
\text { States) }\end{array}$ \\
\hline Armored & $12 / 4 / 2009$ & Saw III & $10 / 27 / 2006$ \\
\hline Saw VI & $10 / 23 / 2009$ & One Night with the King & $10 / 13 / 2006$ \\
\hline The Stepfather (2009) & $10 / 16 / 2009$ & The Marine & $10 / 13 / 2006$ \\
\hline Pandorum & $9 / 25 / 2009$ & The Grudge 2 & $10 / 13 / 2006$ \\
\hline Surrogates & $9 / 25 / 2009$ & The Texas Chainsaw Massacre: The Beginning & $10 / 6 / 2006$ \\
\hline Tyler Perry's I Can Do Bad All By Myself & $9 / 11 / 2009$ & The Covenant & $9 / 8 / 2008$ \\
\hline Sorority Row & $9 / 11 / 2009$ & Crank & $9 / 1 / 2008$ \\
\hline Halloween II (2009) & $8 / 28 / 2009$ & The Wicker Man & $9 / 1 / 2006$ \\
\hline The Final Destination & $8 / 28 / 2009$ & Snakes on a Plane & $8 / 18 / 2006$ \\
\hline G.I. Joe: The Rise of Cobra & $8 / 7 / 2009$ & Pulse & $8 / 11 / 2006$ \\
\hline Aliens in the Attic & $7 / 31 / 2009$ & Zoom & $8 / 11 / 2006$ \\
\hline Obsessed & $4 / 24 / 2009$ & See No Evil & $5 / 19 / 2006$ \\
\hline Crank: High Voltage & $4 / 17 / 2009$ & Silent Hill & $4 / 21 / 2006$ \\
\hline Dragonball Evolution & $4 / 10 / 2009$ & Phat Girlz & $4 / 7 / 2008$ \\
\hline 12 Rounds & $3 / 27 / 2009$ & Benchwarmers, The & $4 / 7 / 2008$ \\
\hline Street Fighter: The Legend of Chun-Li & $2 / 27 / 2009$ & Larry the Cable Guy: Healt.. & $3 / 24 / 2006$ \\
\hline Underworld: Rise of the Lycans & $1 / 23 / 2009$ & Stay Alive & $3 / 24 / 2006$ \\
\hline My Bloody Valentine 3-D & $1 / 16 / 2009$ & Ultraviolet & $3 / 3 / 2008$ \\
\hline The Unborn (2009) & $1 / 9 / 2009$ & Madea's Family Reunion & $2 / 24 / 2006$ \\
\hline The Haunting of Molly Hartley & $10 / 31 / 2008$ & Doogal & $2 / 24 / 2006$ \\
\hline Saw V & $10 / 24 / 2008$ & Date Movie & $2 / 17 / 2006$ \\
\hline Quarantine & $10 / 10 / 2008$ & When a Stranger Calls & $2 / 3 / 2008$ \\
\hline An American Carol & $10 / 3 / 2008$ & Big Momma's House 2 & $1 / 27 / 2006$ \\
\hline Fireproof & $9 / 26 / 2008$ & Underworld: Evolution & $1 / 20 / 2006$ \\
\hline My Best Friend's Girl & $9 / 19 / 2008$ & BloodRayne & $1 / 8 / 2008$ \\
\hline Tyler Perry's The Family That Preys & $9 / 12 / 2008$ & Hostel & $1 / 6 / 2006$ \\
\hline Bangkok Dangerous & $9 / 5 / 2008$ & Aeon Flux & $12 / 2 / 2005$ \\
\hline College & $8 / 29 / 2008$ & Fog. The & $10 / 14 / 2005$ \\
\hline Disaster Movie & $8 / 29 / 2008$ & Cry Wolf & 8/18/2005 \\
\hline Babylon A.D. & $8 / 28 / 2008$ & King's Ransom & $4 / 22 / 2005$ \\
\hline Mirrors & $8 / 15 / 2008$ & Man of the House & $2 / 25 / 2005$ \\
\hline Prom Night (2008) & $4 / 11 / 2008$ & Cursed & $2 / 25 / 2005$ \\
\hline The Ruins & $4 / 4 / 2008$ & Boogeyman & $2 / 4 / 2005$ \\
\hline Superhero Movie & $3 / 28 / 2008$ & Darkness & $12 / 25 / 2004$ \\
\hline Tyler Perry's Meet the Browns & $3 / 21 / 2008$ & Seed of Chucky & $11 / 12 / 2004$ \\
\hline Doomsday & $3 / 14 / 2008$ & The Cookout & $9 / 3 / 2004$ \\
\hline Witless Protection & $2 / 22 / 2008$ & Paparazzi & $9 / 3 / 2004$ \\
\hline Step Up 2 the Streets & $2 / 14 / 2008$ & Exorcist: The Beginning & $8 / 20 / 2004$ \\
\hline Hannah Montana/Miley Cyrus... Concert Tour & $2 / 1 / 2008$ & Alien vs. Predator & $8 / 13 / 2004$ \\
\hline The Eye & $2 / 1 / 2008$ & My Baby's Daddy & $1 / 8 / 2004$ \\
\hline Meet the Spartans & $1 / 25 / 2008$ & House of the Dead & $10 / 10 / 2003$ \\
\hline In the Name of the King: A Dungeon Siege Tale & $1 / 11 / 2008$ & The Order & 9/5/2003 \\
\hline One Missed Call & $1 / 4 / 2008$ & MarciX & $8 / 22 / 2003$ \\
\hline Aliens Vs. Predator - Requiem & $12 / 25 / 2007$ & My Boss's Daughter & $8 / 22 / 2003$ \\
\hline Awake & $11 / 30 / 2007$ & From Justin to Kelly & $6 / 20 / 2003$ \\
\hline Saw IV & $10 / 26 / 2007$ & Wrong Turn & $5 / 30 / 2003$ \\
\hline Tyler Perry's Why Did I Get Married? & $10 / 12 / 2007$ & They & $11 / 27 / 2002$ \\
\hline Resident Evil: Extinction & $9 / 21 / 2007$ & Extreme Ops & $11 / 27 / 2002$ \\
\hline Dragon Wars & $9 / 14 / 2007$ & Trapped & $8 / 20 / 2002$ \\
\hline Halloween (2007) & $8 / 31 / 2007$ & Adventures of Pluto Nash & $8 / 18 / 2002$ \\
\hline WAR & $8 / 24 / 2007$ & Halloween: Resurrection & $7 / 12 / 2002$ \\
\hline The Last Legion & $8 / 17 / 2007$ & Kung Pow: Enter the Fist & $1 / 25 / 2002$ \\
\hline Who's Your Caddy? & $7 / 27 / 2007$ & The Wash & $11 / 14 / 2001$ \\
\hline I Know Who Killed Me & $7 / 27 / 2007$ & Glitter & $9 / 21 / 2001$ \\
\hline Captivity & $7 / 13 / 2007$ & Soul Survivors & $9 / 7 / 2001$ \\
\hline Hostel Part II & $6 / 8 / 2007$ & Get Over It & $3 / 8 / 2001$ \\
\hline The Invisible & $4 / 27 / 2007$ & Valentine & $2 / 2 / 2001$ \\
\hline Slow Burn & $4 / 13 / 2007$ & Sugar and Spice & $1 / 28 / 2001$ \\
\hline Redline & $4 / 13 / 2007$ & Dracula $(2000)$ & $12 / 22 / 2000$ \\
\hline The Hills Have Eyes 2 & $3 / 23 / 2007$ & Dude, Where's My Car? & $12 / 15 / 2000$ \\
\hline Dead Silence & $3 / 16 / 2007$ & Get Carter & $10 / 8 / 2000$ \\
\hline The Abandoned & $2 / 23 / 2007$ & Highlander: Endgame & $9 / 1 / 2000$ \\
\hline Ghost Rider & $2 / 16 / 2007$ & The Art of War & $8 / 25 / 2000$ \\
\hline Tyler Perry's Daddy's Little Girls & $2 / 14 / 2007$ & Autumn in New York & $8 / 11 / 2000$ \\
\hline The Messengers & $2 / 2 / 2007$ & The In Crowd & $7 / 19 / 2000$ \\
\hline Epic Movie & $1 / 26 / 2007$ & Screwed & $5 / 12 / 2000$ \\
\hline Black Christmas (2006) & $12 / 25 / 2006$ & 3 Strikes & $3 / 1 / 2000$ \\
\hline National Lampoon's Van Wilder: The Rise of Taj & $12 / 1 / 2006$ & Down to You & $1 / 21 / 2000$ \\
\hline The Return & $11 / 10 / 2008$ & Supernova & $1 / 14 / 2000$ \\
\hline
\end{tabular}

Table A.1: List of cold openings 


\section{Additional Tables}

Tables A.2 and A.3 provide full regression results for the regressions used in the paper as well as an alternative specification which only includes the variables found to be significantly correlated with box office revenue. Table A.4 shows the results of the regression that determined the propensity score matching results used in this paper. Table A.5 provides the results of different propensity score matching specifications on movies from the years 2000-2005. Table A.6 provides the results of different propensity score matching specifications on movies from the years 2006-2009. Table A.7 displays all parameter estimates for four different specifications of our models. 


\begin{tabular}{|c|c|c|c|c|c|c|}
\hline \multirow{3}{*}{$\begin{array}{l}\text { dependent variable: } \\
\text { period: }\end{array}$} & \multicolumn{6}{|c|}{ log opening weekend box office revenue } \\
\hline & \multicolumn{2}{|c|}{$2000-2009$} & \multicolumn{2}{|c|}{$2000-2005$} & \multicolumn{2}{|c|}{ 2006-2009 } \\
\hline & (1) & $(2)$ & (3) & (4) & $(5)$ & (6) \\
\hline cold opening & $\begin{array}{c}0.204^{* * *} \\
(0.057)\end{array}$ & $\begin{array}{c}0.230^{* * *} \\
(0.053)\end{array}$ & $\begin{array}{c}0.059 \\
(0.084)\end{array}$ & $\begin{array}{c}0.096 \\
(0.098)\end{array}$ & $\begin{array}{c}0.301^{* * *} \\
(0.086)\end{array}$ & $\begin{array}{c}0.348^{* * *} \\
(0.074)\end{array}$ \\
\hline metacritic rating & $\begin{array}{l}0.005^{* * *} \\
(0.001)\end{array}$ & $\begin{array}{c}0.006^{* * *} \\
(0.001)\end{array}$ & $\begin{array}{c}0.004^{* * *} \\
(0.001)\end{array}$ & $\begin{array}{c}0.009^{* * *} \\
(0.001)\end{array}$ & $\begin{array}{c}0.007^{* * *} \\
(0.001)\end{array}$ & $\begin{array}{l}0.005^{* * *} \\
(0.001)\end{array}$ \\
\hline imdb rating & $\begin{array}{c}0.010 \\
(0.020)\end{array}$ & - & $\begin{array}{c}0.040 \\
(0.025)\end{array}$ & - & $\begin{array}{l}-0.040 \\
(0.033)\end{array}$ & - \\
\hline log theaters opened & $\begin{array}{l}1.169^{* * *} \\
(0.067)\end{array}$ & $\begin{array}{l}1.259^{* * *} \\
(0.058)\end{array}$ & $\begin{array}{c}0.999 * * * \\
(0.083)\end{array}$ & $\begin{array}{l}1.023^{\star \star \star} \\
(0.086)\end{array}$ & $\begin{array}{l}1.273^{\star * \star} \\
(0.107)\end{array}$ & $\begin{array}{l}1.273^{* * *} \\
(0.090)\end{array}$ \\
\hline log production budget & $\begin{array}{c}0.011 \\
(0.026)\end{array}$ & - & $\begin{array}{c}-0.072^{\star *} \\
(0.031)\end{array}$ & - & $\begin{array}{l}0.103^{\star *} \\
(0.042)\end{array}$ & - \\
\hline $\begin{array}{l}\text { log advertising } \\
\text { expenditures }\end{array}$ & $\begin{array}{c}0.512^{* * *} \\
(0.044)\end{array}$ & $\begin{array}{l}0.550 * * * \\
(0.038)\end{array}$ & $\begin{array}{c}0.630^{* * *} \\
(0.057)\end{array}$ & $\begin{array}{c}0.837^{* * *} \\
(0.058)\end{array}$ & $\begin{array}{c}0.412^{* * *} \\
(0.067)\end{array}$ & $\begin{array}{l}0.587^{* * *} \\
(0.057)\end{array}$ \\
\hline $\begin{array}{l}\text { average log competitor } \\
\text { budget }\end{array}$ & $\begin{array}{c}-0.053^{* *} \\
(0.023)\end{array}$ & - & $\begin{array}{l}-0.025 \\
(0.032)\end{array}$ & - & $\begin{array}{l}-0.061^{*} \\
(0.034)\end{array}$ & - \\
\hline $\begin{array}{l}\text { average log competitor } \\
\text { advertising expenditures }\end{array}$ & $\begin{array}{l}-0.029 \\
(0.030)\end{array}$ & - & $\begin{array}{l}-0.076^{*} \\
(0.040)\end{array}$ & - & $\begin{array}{c}0.016 \\
(0.046)\end{array}$ & - \\
\hline average log star ranking & $\begin{array}{l}-0.010^{*} \\
(0.006)\end{array}$ & - & $\begin{array}{c}-0.015^{* *} \\
(0.007)\end{array}$ & - & $\begin{array}{l}-0.026^{*} \\
(0.014)\end{array}$ & - \\
\hline summer open & $\begin{array}{c}0.028 \\
(0.035)\end{array}$ & - & $\begin{array}{l}0.081^{* *} \\
(0.041)\end{array}$ & - & $\begin{array}{l}-0.026 \\
(0.060)\end{array}$ & - \\
\hline adaptation or sequel & $\begin{array}{l}0.060^{*} \\
(0.036)\end{array}$ & - & $\begin{array}{c}0.157^{* * *} \\
(0.038)\end{array}$ & - & $\begin{array}{c}-0.313^{* * *} \\
(0.095)\end{array}$ & - \\
\hline $\begin{array}{l}\text { days released before } \\
\text { Friday }\end{array}$ & $\begin{array}{c}0.018 \\
(0.023)\end{array}$ & - & $\begin{array}{c}0.001 \\
(0.027)\end{array}$ & - & $\begin{array}{c}0.026 \\
(0.039)\end{array}$ & - \\
\hline $\begin{array}{l}\text { opening weekend } \\
\text { continues after Sunday }\end{array}$ & $\begin{array}{l}0.115^{\star * *} \\
(0.043)\end{array}$ & $\begin{array}{l}0.114^{* * *} \\
(0.042)\end{array}$ & $\begin{array}{c}0.230^{* * *} \\
(0.053)\end{array}$ & $\begin{array}{l}0.149 * * \\
(0.062)\end{array}$ & $\begin{array}{c}0.011 \\
(0.071)\end{array}$ & $\begin{array}{c}0.010 \\
(0.067)\end{array}$ \\
\hline $\begin{array}{l}\text { months released earlier in } \\
\text { foreign country }\end{array}$ & $\begin{array}{l}-0.008 \\
(0.005)\end{array}$ & - & $\begin{array}{l}-0.005 \\
(0.005)\end{array}$ & - & $\begin{array}{l}-0.015 \\
(0.013)\end{array}$ & - \\
\hline action or adventure & $\begin{array}{c}0.170^{\star * \star} \\
(0.057)\end{array}$ & - & $\begin{array}{c}0.173^{* \star *} \\
(0.066)\end{array}$ & - & $\begin{array}{c}0.130 \\
(0.101)\end{array}$ & - \\
\hline animated & $\begin{array}{c}0.087 \\
(0.084)\end{array}$ & - & $\begin{array}{c}0.068 \\
(0.108)\end{array}$ & - & $\begin{array}{c}0.112 \\
(0.130)\end{array}$ & - \\
\hline comedy & $\begin{array}{c}0.067 \\
(0.047)\end{array}$ & - & $\begin{array}{c}0.064 \\
(0.055)\end{array}$ & - & $\begin{array}{c}0.046 \\
(0.080)\end{array}$ & - \\
\hline documentary & $\begin{array}{c}0.993^{* * *} \\
(0.249)\end{array}$ & $\begin{array}{c}0.480^{* * *} \\
(0.177)\end{array}$ & $\begin{array}{c}0.461 \\
(0.354)\end{array}$ & $\begin{array}{c}0.321 \\
(0.346)\end{array}$ & $\begin{array}{c}1.486^{* * *} \\
(0.363)\end{array}$ & $\begin{array}{c}0.378^{*} \\
(0.229)\end{array}$ \\
\hline fantasy or sci-fi & $\begin{array}{l}0.136^{*} \\
(0.071)\end{array}$ & - & $\begin{array}{c}0.309^{* * *} \\
(0.085)\end{array}$ & - & $\begin{array}{l}-0.143 \\
(0.118)\end{array}$ & - \\
\hline suspense or horror & $\begin{array}{l}0.157^{* * *} \\
(0.056)\end{array}$ & $\begin{array}{l}0.090^{* *} \\
(0.040)\end{array}$ & $\begin{array}{c}0.235^{\star * *} \\
(0.068)\end{array}$ & $\begin{array}{c}0.180^{* * *} \\
(0.061)\end{array}$ & $\begin{array}{c}0.065 \\
(0.092)\end{array}$ & $\begin{array}{c}0.005 \\
(0.061)\end{array}$ \\
\hline year & $\begin{array}{c}-0.038^{* * *} \\
(0.007)\end{array}$ & $\begin{array}{c}-0.029 * * * \\
(0.005)\end{array}$ & $\begin{array}{c}-0.043^{* * *} \\
(0.011)\end{array}$ & $\begin{array}{c}-0.076^{* * *} \\
(0.012)\end{array}$ & $\begin{array}{c}0.038 \\
(0.025)\end{array}$ & $\begin{array}{l}0.038^{*} \\
(0.022)\end{array}$ \\
\hline $\mathrm{pg}$ & $\begin{array}{c}-0.066 \\
(0.093)\end{array}$ & - & $\begin{array}{c}-0.052 \\
(0.110)\end{array}$ & - & $\begin{array}{c}0.018 \\
(0.165)\end{array}$ & - \\
\hline pg13 & $\begin{array}{c}0.054 \\
(0.097)\end{array}$ & - & $\begin{array}{c}0.004 \\
(0.114)\end{array}$ & - & $\begin{array}{c}0.233 \\
(0.173)\end{array}$ & - \\
\hline r & $\begin{array}{l}-0.001 \\
(0.100)\end{array}$ & - & $\begin{array}{l}-0.003 \\
(0.117)\end{array}$ & - & $\begin{array}{c}0.126 \\
(0.180)\end{array}$ & - \\
\hline constant & $\begin{array}{c}-8.183^{* * *} \\
(0.486)\end{array}$ & $\begin{array}{c}-9.134^{\star * *} \\
(0.381)\end{array}$ & $\begin{array}{c}-7.001^{\star * *} \\
(0.620)\end{array}$ & $\begin{array}{c}-7.205^{\star \star *} \\
(0.570)\end{array}$ & $\begin{array}{c}-8.932^{* * *} \\
(0.796)\end{array}$ & $\begin{array}{c}-9.63^{* * *} \\
(0.594)\end{array}$ \\
\hline observations & 1303 & 1413 & 778 & 797 & 525 & 616 \\
\hline $\mathrm{R}^{2}$ & 0.684 & 0.684 & 0.712 & 0.681 & 0.702 & 0.697 \\
\hline
\end{tabular}

Table A.2: Regressions on logged weekend box office revenues (in millions) 


\begin{tabular}{|c|c|c|c|c|c|c|}
\hline \multirow{3}{*}{$\begin{array}{l}\text { dependent variable: } \\
\text { period: }\end{array}$} & \multicolumn{6}{|c|}{ log total box office revenue } \\
\hline & \multicolumn{2}{|c|}{$2000-2009$} & \multicolumn{2}{|c|}{$2000-2005$} & \multicolumn{2}{|c|}{$2006-2009$} \\
\hline & (1) & (2) & (3) & (4) & (5) & (6) \\
\hline cold opening & $\begin{array}{l}0.292^{* * *} \\
(0.064)\end{array}$ & $\begin{array}{l}0.241^{* * *} \\
(0.060)\end{array}$ & $\begin{array}{c}0.123 \\
(0.095)\end{array}$ & $\begin{array}{c}0.096 \\
(0.098)\end{array}$ & $\begin{array}{c}0.386^{* * *} \\
(0.097)\end{array}$ & $\begin{array}{l}0.320^{* * *} \\
(0.082)\end{array}$ \\
\hline metacritic rating & $\begin{array}{c}0.005^{\star * *} \\
(0.001)\end{array}$ & $\begin{array}{l}0.008^{* * *} \\
(0.001)\end{array}$ & $\begin{array}{c}0.005^{* * *} \\
(0.001)\end{array}$ & $\begin{array}{c}0.009^{* * *} \\
(0.001)\end{array}$ & $\begin{array}{c}0.006^{* * *} \\
(0.002)\end{array}$ & $\begin{array}{c}0.007^{* * *} \\
(0.001)\end{array}$ \\
\hline imdb rating & $\begin{array}{l}0.100 * * * \\
(0.022)\end{array}$ & - & $\begin{array}{l}0.122^{* * *} \\
(0.028)\end{array}$ & - & $\begin{array}{l}0.069^{*} \\
(0.037)\end{array}$ & - \\
\hline log theaters opened & $\begin{array}{c}0.989^{* * *} \\
(0.075)\end{array}$ & $\begin{array}{l}1.127^{* * *} \\
(0.065)\end{array}$ & $\begin{array}{c}0.823^{* * *} \\
(0.095)\end{array}$ & $\begin{array}{l}1.023^{* * *} \\
(0.086)\end{array}$ & $\begin{array}{l}1.092^{* * *} \\
(0.121)\end{array}$ & $\begin{array}{l}1.193^{* * *} \\
(0.099)\end{array}$ \\
\hline log production budget & $\begin{array}{c}0.008 \\
(0.029)\end{array}$ & - & $\begin{array}{c}-0.098^{* * *} \\
(0.036)\end{array}$ & - & $\begin{array}{c}0.127^{* * *} \\
(0.047)\end{array}$ & - \\
\hline $\begin{array}{l}\text { log advertising } \\
\text { expenditures }\end{array}$ & $\begin{array}{l}0.742^{\star * *} \\
(0.049)\end{array}$ & $\begin{array}{l}0.807^{* * *} \\
(0.042)\end{array}$ & $\begin{array}{l}0.921^{* * *} \\
(0.065)\end{array}$ & $\begin{array}{l}0.837^{* * *} \\
(0.058)\end{array}$ & $\begin{array}{l}0.595^{\star * *} \\
(0.075)\end{array}$ & $\begin{array}{c}0.810^{* * *} \\
(0.063)\end{array}$ \\
\hline $\begin{array}{l}\text { average log competitor } \\
\text { budget }\end{array}$ & $\begin{array}{l}-0.021 \\
(0.026)\end{array}$ & - & $\begin{array}{l}-0.009 \\
(0.036)\end{array}$ & - & $\begin{array}{l}-0.017 \\
(0.038)\end{array}$ & - \\
\hline $\begin{array}{l}\text { average log competitor } \\
\text { advertising expenditures }\end{array}$ & $\begin{array}{l}-0.033 \\
(0.034)\end{array}$ & - & $\begin{array}{l}-0.077^{*} \\
(0.046)\end{array}$ & - & $\begin{array}{c}0.011 \\
(0.051)\end{array}$ & - \\
\hline average log star ranking & $\begin{array}{l}-0.015^{\star *} \\
(0.006)\end{array}$ & - & $\begin{array}{l}-0.015^{*} \\
(0.008)\end{array}$ & - & $\begin{array}{l}-0.026^{*} \\
(0.016)\end{array}$ & - \\
\hline summer open & $\begin{array}{l}0.079 * * \\
(0.039)\end{array}$ & - & $\begin{array}{c}0.134^{* * *} \\
(0.047)\end{array}$ & - & $\begin{array}{c}0.022 \\
(0.067)\end{array}$ & - \\
\hline adaptation or sequel & $\begin{array}{l}0.106^{* * *} \\
(0.041)\end{array}$ & - & $\begin{array}{l}0.170^{* * *} \\
(0.044)\end{array}$ & - & $\begin{array}{l}-0.196 * \\
(0.107)\end{array}$ & - \\
\hline $\begin{array}{l}\text { days released before } \\
\text { Friday }\end{array}$ & $\begin{array}{c}0.040 \\
(0.026)\end{array}$ & - & $\begin{array}{l}0.058^{*} \\
(0.031)\end{array}$ & - & $\begin{array}{c}0.021 \\
(0.043)\end{array}$ & - \\
\hline $\begin{array}{l}\text { opening weekend } \\
\text { continues after Sunday }\end{array}$ & $\begin{array}{l}0.134^{* * *} \\
(0.048)\end{array}$ & $\begin{array}{l}0.104^{* *} \\
(0.048)\end{array}$ & $\begin{array}{c}0.173^{* * *} \\
(0.060)\end{array}$ & $\begin{array}{l}0.149^{* *} \\
(0.062)\end{array}$ & $\begin{array}{c}0.119 \\
(0.080)\end{array}$ & $\begin{array}{c}0.060 \\
(0.074)\end{array}$ \\
\hline $\begin{array}{l}\text { months released earlier in } \\
\text { foreign country }\end{array}$ & $\begin{array}{l}-0.010^{*} \\
(0.006)\end{array}$ & - & $\begin{array}{l}-0.005 \\
(0.006)\end{array}$ & - & $\begin{array}{l}-0.025^{\star} \\
(0.014)\end{array}$ & - \\
\hline action or adventure & $\begin{array}{l}0.121^{*} \\
(0.064)\end{array}$ & - & $\begin{array}{l}0.127^{*} \\
(0.075)\end{array}$ & - & $\begin{array}{c}0.088 \\
(0.113)\end{array}$ & - \\
\hline animated & $\begin{array}{c}0.006 \\
(0.095)\end{array}$ & - & $\begin{array}{l}-0.057 \\
(0.123)\end{array}$ & - & $\begin{array}{c}0.045 \\
(0.146)\end{array}$ & - \\
\hline comedy & $\begin{array}{l}0.110^{* *} \\
(0.053)\end{array}$ & - & $\begin{array}{c}0.101 \\
(0.063)\end{array}$ & - & $\begin{array}{c}0.108 \\
(0.090)\end{array}$ & - \\
\hline documentary & $\begin{array}{c}1.037^{* * *} \\
(0.281)\end{array}$ & $\begin{array}{l}0.381^{*} \\
(0.200)\end{array}$ & $\begin{array}{c}0.563 \\
(0.404)\end{array}$ & $\begin{array}{c}0.321 \\
(0.346)\end{array}$ & $\begin{array}{c}1.490^{* * *} \\
(0.409)\end{array}$ & $\begin{array}{c}0.308 \\
(0.253)\end{array}$ \\
\hline fantasy or sci-fi & $\begin{array}{c}0.045 \\
(0.080)\end{array}$ & - & $\begin{array}{c}0.172^{*} \\
(0.096)\end{array}$ & - & $\begin{array}{l}-0.169 \\
(0.133)\end{array}$ & - \\
\hline suspense or horror & $\begin{array}{l}0.156^{\star *} \\
(0.063)\end{array}$ & $\begin{array}{c}0.055 \\
(0.045)\end{array}$ & $\begin{array}{c}0.285^{\star \star \star} \\
(0.078)\end{array}$ & $\begin{array}{c}0.180^{* * *} \\
(0.061)\end{array}$ & $\begin{array}{c}0.038 \\
(0.104)\end{array}$ & $\begin{array}{l}-0.071 \\
(0.067)\end{array}$ \\
\hline year & $\begin{array}{c}-0.062^{* * *} \\
(0.008)\end{array}$ & $\begin{array}{c}-0.042^{* * *} \\
(0.006)\end{array}$ & $\begin{array}{c}-0.079^{* * *} \\
(0.012)\end{array}$ & $\begin{array}{c}-0.076^{* * *} \\
(0.012)\end{array}$ & $\begin{array}{c}0.016 \\
(0.028)\end{array}$ & $\begin{array}{c}0.026 \\
(0.024)\end{array}$ \\
\hline $\mathrm{pg}$ & $\begin{array}{l}-0.182^{*} \\
(0.105)\end{array}$ & - & $\begin{array}{l}-0.213^{*} \\
(0.125)\end{array}$ & - & $\begin{array}{l}-0.095 \\
(0.185)\end{array}$ & - \\
\hline $\mathrm{pg} 13$ & $\begin{array}{c}-0.222^{* *} \\
(0.109)\end{array}$ & - & $\begin{array}{c}-0.307^{* *} \\
(0.130)\end{array}$ & - & $\begin{array}{l}-0.040 \\
(0.194)\end{array}$ & - \\
\hline r & $\begin{array}{c}-0.359^{* * *} \\
(0.113)\end{array}$ & - & $\begin{array}{c}-0.383^{* * *} \\
(0.134)\end{array}$ & - & $\begin{array}{l}-0.266 \\
(0.203)\end{array}$ & - \\
\hline constant & $\begin{array}{c}-6.697^{* * *} \\
(0.548)\end{array}$ & $\begin{array}{c}-7.858^{* * *} \\
(0.431)\end{array}$ & $\begin{array}{c}-5.566^{* * *} \\
(0.707)\end{array}$ & $\begin{array}{c}-7.205^{\star * *} \\
(0.570)\end{array}$ & $\begin{array}{c}-7.589 * * * \\
(0.896)\end{array}$ & $\begin{array}{c}-8.622^{* * *} \\
(0.657)\end{array}$ \\
\hline observations & 1303 & 1413 & 778 & 797 & 525 & 616 \\
\hline $\mathrm{R}^{2}$ & 0.700 & 0.702 & 0.727 & 0.693 & 0.707 & 0.718 \\
\hline
\end{tabular}

Table A.3: Regressions of logged total box office revenues (in millions) 


\begin{tabular}{|c|c|c|c|}
\hline \multirow{2}{*}{$\begin{array}{l}\text { dependent variable: } \\
\text { period: }\end{array}$} & \multicolumn{3}{|c|}{ cold opening } \\
\hline & $\begin{array}{c}2000-2009 \\
(1)\end{array}$ & $\begin{array}{c}2000-2006 \\
(2)\end{array}$ & $\begin{array}{c}2006-2009 \\
\text { (3) }\end{array}$ \\
\hline metacritic rating & $\begin{array}{c}-0.024^{* * *} \\
0.007\end{array}$ & $\begin{array}{l}-0.051^{* * *} \\
0.017\end{array}$ & $\begin{array}{l}-0.017^{*} \\
0.009\end{array}$ \\
\hline imdb rating & $\begin{array}{c}-0.833^{* * *} \\
0.142\end{array}$ & $\begin{array}{c}-0.592^{* *} \\
0.241\end{array}$ & $\begin{array}{c}-1.096^{* * *} \\
0.236\end{array}$ \\
\hline log theaters opened & $\begin{array}{c}0.966^{*} \\
0.539\end{array}$ & $\begin{array}{l}0.023 \\
0.900\end{array}$ & $\begin{array}{c}2.301^{* *} \\
0.937\end{array}$ \\
\hline log production budget & $\begin{array}{l}-0.644^{* * *} \\
0.187\end{array}$ & $\begin{array}{l}-0.471^{*} \\
0.286\end{array}$ & $\begin{array}{c}-0.816^{* * *} \\
0.309\end{array}$ \\
\hline $\begin{array}{l}\text { log advertising } \\
\text { expenditures }\end{array}$ & $\begin{array}{l}-1.336^{* * *} \\
0.295\end{array}$ & $\begin{array}{c}-0.594 \\
0.498\end{array}$ & $\begin{array}{l}-1.896^{* * *} \\
0.486\end{array}$ \\
\hline $\begin{array}{l}\text { average log competitor } \\
\text { budget }\end{array}$ & $\begin{array}{c}-0.094 \\
0.171\end{array}$ & $\begin{array}{l}0.216 \\
0.340\end{array}$ & $\begin{array}{r}-0.244 \\
0.247\end{array}$ \\
\hline $\begin{array}{l}\text { average log competitor } \\
\text { advertising expenditures }\end{array}$ & $\begin{array}{l}-0.050 \\
0.226\end{array}$ & $\begin{array}{c}-0.048 \\
0.389\end{array}$ & $\begin{array}{c}-0.252 \\
0.361\end{array}$ \\
\hline average log star ranking & $\begin{array}{c}-0.071 \\
0.051\end{array}$ & $\begin{array}{l}0.022 \\
0.075\end{array}$ & $\begin{array}{l}0.053 \\
0.104\end{array}$ \\
\hline summer open & $\begin{array}{c}-0.192 \\
0.303\end{array}$ & $\begin{array}{r}-0.002 \\
0.474\end{array}$ & $\begin{array}{c}-0.040 \\
0.475\end{array}$ \\
\hline adaptation or sequel & $\begin{array}{c}-0.416 \\
0.333\end{array}$ & $\begin{array}{c}-0.448 \\
0.486\end{array}$ & $\begin{array}{c}-1.070 \\
0.679\end{array}$ \\
\hline $\begin{array}{l}\text { days released before } \\
\text { Friday }\end{array}$ & $\begin{array}{c}-0.078 \\
0.212\end{array}$ & $\begin{array}{c}-0.011 \\
0.351\end{array}$ & $\begin{array}{c}-0.406 \\
0.365\end{array}$ \\
\hline $\begin{array}{l}\text { opening weekend } \\
\text { continues after Sunday }\end{array}$ & $\begin{array}{l}0.086 \\
0.368\end{array}$ & $\begin{array}{r}-0.297 \\
0.619\end{array}$ & $\begin{array}{l}0.726 \\
0.581\end{array}$ \\
\hline $\begin{array}{l}\text { months released earlier in } \\
\text { foreign country }\end{array}$ & $\begin{array}{c}-0.022 \\
0.049\end{array}$ & $\begin{array}{r}-0.001 \\
0.077\end{array}$ & $\begin{array}{c}-0.096 \\
0.081\end{array}$ \\
\hline action or adventure & $\begin{array}{l}1.876^{* * *} \\
0.662\end{array}$ & $\begin{array}{l}0.241 \\
1.078\end{array}$ & $\begin{array}{l}3.398^{* * *} \\
1.146\end{array}$ \\
\hline animated & $\begin{array}{l}-0.835 \\
1.356\end{array}$ & $(\text { omitted })^{a}$ & $\begin{array}{r}-1.670 \\
1.783\end{array}$ \\
\hline comedy & $\begin{array}{l}0.765 \\
0.571\end{array}$ & $\begin{array}{l}0.891 \\
0.790\end{array}$ & $\begin{array}{l}0.700 \\
1.007\end{array}$ \\
\hline documentary & $\begin{array}{l}0.110 \\
1.463\end{array}$ & 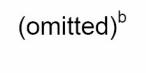 & $\begin{array}{l}0.472 \\
2.025\end{array}$ \\
\hline fantasy or sci-fi & $\begin{array}{l}2.840^{* * *} \\
0.727\end{array}$ & $\begin{array}{l}3.110^{* * *} \\
1.069\end{array}$ & $\begin{array}{l}3.853^{* * *} \\
1.234\end{array}$ \\
\hline suspense or horror & $\begin{array}{l}2.507^{* * *} \\
0.602\end{array}$ & $\begin{array}{c}2.427^{* * *} \\
0.835\end{array}$ & $\begin{array}{c}3.236^{* * *} \\
1.057\end{array}$ \\
\hline year & $\begin{array}{c}0.296^{* * *} \\
0.063\end{array}$ & $\begin{array}{l}0.055 \\
0.116\end{array}$ & $\begin{array}{l}0.058 \\
0.199\end{array}$ \\
\hline $\mathrm{pg}$ & $\begin{array}{r}-1.737 \\
1.074\end{array}$ & $\begin{array}{c}14.114 \\
1498.291\end{array}$ & $\begin{array}{c}-2.266 \\
1.468\end{array}$ \\
\hline $\operatorname{pg} 13$ & $\begin{array}{l}0.183 \\
0.988\end{array}$ & $\begin{array}{c}16.569 \\
1498.291\end{array}$ & $\begin{array}{c}-0.456 \\
1.415\end{array}$ \\
\hline r & $\begin{array}{l}0.016 \\
1.015\end{array}$ & $\begin{array}{c}15.916 \\
1498.291\end{array}$ & $\begin{array}{c}-0.405 \\
1.528\end{array}$ \\
\hline constant & $\begin{array}{l}0.220 \\
3.899\end{array}$ & $\begin{array}{c}-13.839 \\
1498.305\end{array}$ & $\begin{array}{c}-4.931 \\
6.920\end{array}$ \\
\hline observations & 1303 & $731^{\circ}$ & 525 \\
\hline log likelihood & -230.138 & -97.104 & -103.672 \\
\hline
\end{tabular}

Table A.4: Logistic regression on cold opening of independent variables 


\begin{tabular}{|c|c|c|c|c|c|c|}
\hline dependent variable: & specification & $\begin{array}{c}\text { number in } \\
\text { treatment } \\
\text { group }\end{array}$ & $\begin{array}{c}\text { number in } \\
\text { control group }\end{array}$ & $\begin{array}{c}\text { average } \\
\text { treatment } \\
\text { effect on the } \\
\text { treated }\end{array}$ & $\begin{array}{l}\text { standard } \\
\text { error }\end{array}$ & t-statistic \\
\hline $\begin{array}{l}\text { log opening weekend } \\
\text { box office revenue }\end{array}$ & nearest neighbor & 43 & 31 & -0.132 & 0.234 & -0.565 \\
\hline $\begin{array}{l}\text { log opening weekend } \\
\text { box office revenue }\end{array}$ & stratification & 41 & 248 & -0.046 & 0.165 & -0.277 \\
\hline $\begin{array}{l}\text { log opening weekend } \\
\text { box office revenue }\end{array}$ & kernel matching & 43 & 246 & -0.087 & 0.227 & -0.385 \\
\hline $\begin{array}{l}\text { log total box office } \\
\text { revenue }\end{array}$ & nearest neighbor & 43 & 31 & -0.145 & 0.273 & -0.531 \\
\hline $\begin{array}{l}\text { log total box office } \\
\text { revenue }\end{array}$ & stratification & 41 & 248 & -0.023 & 0.176 & -0.131 \\
\hline $\begin{array}{l}\text { log total box office } \\
\text { revenue }\end{array}$ & kernel matching & 43 & 246 & -0.051 & 0.265 & -0.191 \\
\hline
\end{tabular}

Table A.5: Propensity score matching results for logged US cumulative and weekend box office, 2000-2005. Cold opening is the treatment variable. A logit regression including all 23 variables and a constant (see table A.4) was used to generate propensity scores. All specifications are over the area of common support.

\begin{tabular}{|c|c|c|c|c|c|c|}
\hline dependent variable: & specification & $\begin{array}{c}\text { number in } \\
\text { treatment } \\
\text { group }\end{array}$ & $\begin{array}{c}\text { number in } \\
\text { control group }\end{array}$ & $\begin{array}{c}\text { average } \\
\text { treatment } \\
\text { effect on the } \\
\text { treated }\end{array}$ & $\begin{array}{l}\text { standard } \\
\text { error }\end{array}$ & t-statistic \\
\hline $\begin{array}{l}\text { log opening weekend } \\
\text { box office revenue }\end{array}$ & nearest neighbor & 95 & 36 & 0.467 & 0.345 & 1.354 \\
\hline $\begin{array}{l}\text { log opening weekend } \\
\text { box office revenue }\end{array}$ & stratification & 95 & 208 & 0.434 & 0.127 & $3.422^{* * *}$ \\
\hline $\begin{array}{l}\text { log opening weekend } \\
\text { box office revenue }\end{array}$ & kernel matching & 95 & 208 & 0.403 & 0.127 & $3.174^{* * *}$ \\
\hline $\begin{array}{l}\text { log total box office } \\
\text { revenue }\end{array}$ & nearest neighbor & 95 & 36 & 0.499 & 0.368 & 1.357 \\
\hline $\begin{array}{l}\text { log total box office } \\
\text { revenue }\end{array}$ & stratification & 95 & 208 & 0.475 & 0.147 & $3.24^{\star * *}$ \\
\hline $\begin{array}{l}\text { log total box office } \\
\text { revenue }\end{array}$ & kernel matching & 95 & 208 & 0.449 & 0.160 & $2.805^{* * *}$ \\
\hline
\end{tabular}

Table A.6: Propensity score matching results for logged US cumulative and weekend box office, 2006-2009. Cold opening is the treatment variable. A logit regression including all 23 variables and a constant (see table A.4) was used to generate propensity scores. All specifications are over the area of common support. 


\begin{tabular}{|c|c|c|c|c|c|c|c|c|}
\hline \multirow{3}{*}{$\begin{array}{l}\text { dependent variable: } \\
\text { model: } \\
\text { period: }\end{array}$} & \multicolumn{8}{|c|}{ moviegoer attends movie } \\
\hline & \multicolumn{2}{|c|}{ baseline } & \multicolumn{2}{|c|}{$\begin{array}{c}\text { baseline, correct Bayesian } \\
\text { expectations }\end{array}$} & \multicolumn{2}{|c|}{$\begin{array}{c}\text { baseline, free } \mathrm{E}(\mathrm{q} \mid 1) \\
\text { parameter }\end{array}$} & \multicolumn{2}{|c|}{ Cognitive Hierarchy } \\
\hline & $\begin{array}{l}2000-2005 \\
\text { (1) }\end{array}$ & $\begin{array}{c}2006-2009 \\
\text { (2) }\end{array}$ & $\begin{array}{c}2000-2005 \\
\text { (3) }\end{array}$ & $\begin{array}{c}2006-2009 \\
\text { (4) }\end{array}$ & $\begin{array}{c}2000-2005 \\
\text { (5) }\end{array}$ & $\begin{array}{c}2006-2009 \\
(6)\end{array}$ & $\begin{array}{c}2000-2005 \\
\text { (7) }\end{array}$ & $\begin{array}{c}2006-2009 \\
\text { (8) }\end{array}$ \\
\hline $\begin{array}{l}\text { expected quality of cold- } \\
\text { opened movie }\left(E\left(q_{j} \mid 1\right)\right)\end{array}$ & 0.000 & 0.000 & - & - & $\begin{array}{c}0.000 \\
(0.000)\end{array}$ & $\begin{array}{l}9.121^{* *} \\
(3.398)\end{array}$ & - & - \\
\hline $\begin{array}{l}\text { moviegoer mean steps of } \\
\text { thinking }(T)\end{array}$ & - & - & - & - & - & - & $\begin{array}{c}1.638 \\
(9.927)\end{array}$ & $\begin{array}{c}0.000 \\
(0.000)\end{array}$ \\
\hline $\begin{array}{l}\text { studio mean steps of } \\
\text { thinking }(T)\end{array}$ & - & - & - & - & - & - & $\begin{array}{c}100.000^{* * *} \\
(13.229)\end{array}$ & $\begin{array}{l}5.022 \\
(9.636)\end{array}$ \\
\hline metacritic rating & $\begin{array}{c}0.008^{\star \star \star *} \\
(0.001)\end{array}$ & $\begin{array}{l}0.004^{* * *} \\
(0.000)\end{array}$ & $\begin{array}{c}3.572 \mathrm{E}- \\
(7.208 \mathrm{E}-06)\end{array}$ & $\begin{array}{c}9.882 \mathrm{E}- \\
(1.310 \mathrm{E}-05)\end{array}$ & $\begin{array}{l}0.008^{* * *} \\
(0.001)\end{array}$ & $\begin{array}{l}0.005^{\star \star \star} \\
(0.001)\end{array}$ & $\begin{array}{l}0.008^{* * *} \\
(0.001)\end{array}$ & $\begin{array}{l}0.006^{* \star *} \\
(0.001)\end{array}$ \\
\hline imdb rating & $\begin{array}{l}-0.023 \\
(0.027)\end{array}$ & $\begin{array}{l}-0.012 \\
(0.029)\end{array}$ & $\begin{array}{l}0.120^{* * *} \\
(0.022)\end{array}$ & $\begin{array}{c}0.022 \\
(0.030)\end{array}$ & $\begin{array}{l}-0.022 \\
(0.027)\end{array}$ & $\begin{array}{l}-0.028 \\
(0.028)\end{array}$ & $\begin{array}{l}-0.018 \\
(0.028)\end{array}$ & $\begin{array}{l}-0.014 \\
(0.029)\end{array}$ \\
\hline log theaters opened & $\begin{array}{l}1.061^{\star * *} \\
(0.100)\end{array}$ & $\begin{array}{l}1.299^{* * *} \\
(0.146)\end{array}$ & $\begin{array}{l}1.003^{* * *} \\
(0.091)\end{array}$ & $\begin{array}{l}1.368^{\star \star \star} \\
(0.134)\end{array}$ & $\begin{array}{l}1.070^{\star * *} \\
(0.098)\end{array}$ & $\begin{array}{l}1.317^{\star \star \star \star} \\
(0.147)\end{array}$ & $\begin{array}{l}1.057^{* * \star} \\
(0.099)\end{array}$ & $\begin{array}{l}1.284^{\star * *} \\
(0.142)\end{array}$ \\
\hline log production budget & $\begin{array}{l}-0.066^{*} \\
(0.036)\end{array}$ & $\begin{array}{l}0.117^{* *} \\
(0.056)\end{array}$ & $\begin{array}{l}-0.061 \\
(0.037)\end{array}$ & $\begin{array}{l}0.110^{*} \\
(0.058)\end{array}$ & $\begin{array}{l}-0.065^{*} \\
(0.036)\end{array}$ & $\begin{array}{l}0.119^{* \star} \\
(0.057)\end{array}$ & $\begin{array}{l}-0.065^{*} \\
(0.036)\end{array}$ & $\begin{array}{l}0.131^{\star \star} \\
(0.056)\end{array}$ \\
\hline $\begin{array}{l}\text { log advertising } \\
\text { expenditures }\end{array}$ & $\begin{array}{l}0.621^{\star \star \star} \\
(0.081)\end{array}$ & $\begin{array}{l}0.406^{* * *} \\
(0.091)\end{array}$ & $\begin{array}{l}0.687^{\star \star \star *} \\
(0.084)\end{array}$ & $\begin{array}{l}0.416^{\star \star \star} \\
(0.093)\end{array}$ & $\begin{array}{l}0.616^{\star * *} \\
(0.080)\end{array}$ & $\begin{array}{l}0.396^{\star \star \star} \\
(0.093)\end{array}$ & $\begin{array}{l}0.634^{* \star \star} \\
(0.083)\end{array}$ & $\begin{array}{l}0.426^{\star \star \star} \\
(0.091)\end{array}$ \\
\hline $\begin{array}{l}\text { average log competitor } \\
\text { budget }\end{array}$ & $\begin{array}{l}-0.040 \\
(0.036)\end{array}$ & $\begin{array}{l}-0.069^{*} \\
(0.036)\end{array}$ & $\begin{array}{l}-0.033 \\
(0.038)\end{array}$ & $\begin{array}{l}-0.060^{*} \\
(0.035)\end{array}$ & $\begin{array}{l}-0.039 \\
(0.036)\end{array}$ & $\begin{array}{l}-0.074^{*} \\
(0.036)\end{array}$ & $\begin{array}{l}-0.044 \\
(0.036)\end{array}$ & $\begin{array}{l}-0.071^{*} \\
(0.036)\end{array}$ \\
\hline $\begin{array}{l}\text { average log competitor } \\
\text { advertising expenditures }\end{array}$ & $\begin{array}{l}-0.079 \\
(0.049)\end{array}$ & $\begin{array}{c}0.010 \\
(0.053)\end{array}$ & $\begin{array}{l}-0.089^{*} \\
(0.052)\end{array}$ & $\begin{array}{l}-0.001 \\
(0.047)\end{array}$ & $\begin{array}{l}-0.080 \\
(0.049)\end{array}$ & $\begin{array}{l}0.016 \\
(0.054)\end{array}$ & $\begin{array}{l}-0.074 \\
(0.049)\end{array}$ & $\begin{array}{c}0.019 \\
(0.054)\end{array}$ \\
\hline average log star ranking & $\begin{array}{l}-0.020^{* *} \\
(0.008)\end{array}$ & $\begin{array}{l}-0.025 \\
(0.015)\end{array}$ & $\begin{array}{l}-0.015^{*} \\
(0.008)\end{array}$ & $\begin{array}{l}-0.032^{*} \\
(0.016)\end{array}$ & $\begin{array}{l}-0.020^{* *} \\
(0.008)\end{array}$ & $\begin{array}{l}-0.024 \\
(0.015)\end{array}$ & $\begin{array}{l}-0.020^{* *} \\
(0.008)\end{array}$ & $\begin{array}{l}-0.026^{*} \\
(0.015)\end{array}$ \\
\hline summer open & $\begin{array}{c}0.072 \\
(0.050)\end{array}$ & $\begin{array}{l}-0.014 \\
(0.057)\end{array}$ & $\begin{array}{l}0.105^{* *} \\
(0.050)\end{array}$ & $\begin{array}{l}-0.004 \\
(0.055)\end{array}$ & $\begin{array}{c}0.072 \\
(0.050)\end{array}$ & $\begin{array}{l}-0.014 \\
(0.057)\end{array}$ & $\begin{array}{c}0.073 \\
(0.050)\end{array}$ & $\begin{array}{l}-0.018 \\
(0.057)\end{array}$ \\
\hline adaptation or sequel & $\begin{array}{l}0.153^{* \star *} \\
(0.038)\end{array}$ & $\begin{array}{c}-0.336^{* \star *} \\
(0.079)\end{array}$ & $\begin{array}{l}0.191^{* * *} \\
(0.039)\end{array}$ & $\begin{array}{c}-0.373^{* * *} \\
(0.083)\end{array}$ & $\begin{array}{l}0.153^{* * *} \\
(0.038)\end{array}$ & $\begin{array}{c}-0.344^{* * *} \\
(0.080)\end{array}$ & $\begin{array}{l}0.157^{* \star *} \\
(0.039)\end{array}$ & $\begin{array}{l}-0.332^{\star \star \star} \\
(0.081)\end{array}$ \\
\hline $\begin{array}{l}\text { days released before } \\
\text { Friday }\end{array}$ & $\begin{array}{c}0.003 \\
(0.035)\end{array}$ & $\begin{array}{c}0.025 \\
(0.045)\end{array}$ & $\begin{array}{c}0.015 \\
(0.033)\end{array}$ & $\begin{array}{c}0.019 \\
(0.045)\end{array}$ & $\begin{array}{c}0.002 \\
(0.035)\end{array}$ & $\begin{array}{c}0.021 \\
(0.045)\end{array}$ & $\begin{array}{l}-0.001 \\
(0.034)\end{array}$ & $\begin{array}{c}0.027 \\
(0.046)\end{array}$ \\
\hline $\begin{array}{l}\text { opening weekend } \\
\text { continues after Sunday }\end{array}$ & $\begin{array}{l}0.257^{\star \star \star *} \\
(0.057)\end{array}$ & $\begin{array}{l}0.023 \\
(0.084)\end{array}$ & $\begin{array}{l}0.247^{\star \star \star \star} \\
(0.059)\end{array}$ & $\begin{array}{c}0.002 \\
(0.082)\end{array}$ & $\begin{array}{l}0.257^{\star \star *} \\
(0.057)\end{array}$ & $\begin{array}{l}0.020 \\
(0.085)\end{array}$ & $\begin{array}{l}0.259^{* \star \star} \\
(0.057)\end{array}$ & $\begin{array}{c}0.003 \\
(0.087)\end{array}$ \\
\hline $\begin{array}{l}\text { months released earlier in } \\
\text { foreign country }\end{array}$ & $\begin{array}{l}-0.004 \\
(0.007)\end{array}$ & $\begin{array}{l}-0.014 \\
(0.017)\end{array}$ & $\begin{array}{l}0.000 \\
(0.006)\end{array}$ & $\begin{array}{l}0.000 \\
(0.001)\end{array}$ & $\begin{array}{l}-0.004 \\
(0.007)\end{array}$ & $\begin{array}{l}-0.013 \\
(0.016)\end{array}$ & $\begin{array}{l}-0.004 \\
(0.006)\end{array}$ & $\begin{array}{l}-0.011 \\
(0.017)\end{array}$ \\
\hline action or adventure & $\begin{array}{l}0.188^{\star \star \star *} \\
(0.065)\end{array}$ & $\begin{array}{c}0.152 \\
(0.097)\end{array}$ & $\begin{array}{l}0.205^{\star \star \star} \\
(0.065)\end{array}$ & $\begin{array}{c}0.141 \\
(0.093)\end{array}$ & $\begin{array}{l}0.186^{\star \star *} \\
(0.065)\end{array}$ & $\begin{array}{l}0.160 \\
(0.097)\end{array}$ & $\begin{array}{l}0.191^{* \star \star} \\
(0.066)\end{array}$ & $\begin{array}{l}0.126 \\
(0.096)\end{array}$ \\
\hline animated & $\begin{array}{l}0.066 \\
(0.139)\end{array}$ & $\begin{array}{c}0.122 \\
(0.136)\end{array}$ & $\begin{array}{c}0.149 \\
(0.124)\end{array}$ & $\begin{array}{l}0.127 \\
(0.143)\end{array}$ & $\begin{array}{c}0.063 \\
(0.139)\end{array}$ & $\begin{array}{l}0.122 \\
(0.136)\end{array}$ & $\begin{array}{l}0.058 \\
(0.139)\end{array}$ & $\begin{array}{c}0.103 \\
(0.135)\end{array}$ \\
\hline comedy & $\begin{array}{l}0.077 \\
(0.062)\end{array}$ & $\begin{array}{c}0.040 \\
(0.089)\end{array}$ & $\begin{array}{l}0.078 \\
(0.064)\end{array}$ & $\begin{array}{l}0.005 \\
(0.087)\end{array}$ & $\begin{array}{l}0.076 \\
(0.062)\end{array}$ & $\begin{array}{c}0.035 \\
(0.088)\end{array}$ & $\begin{array}{c}0.081 \\
(0.063)\end{array}$ & $\begin{array}{c}0.043 \\
(0.088)\end{array}$ \\
\hline documentary & $\begin{array}{c}0.483 \\
(16.416)\end{array}$ & $\begin{array}{c}1.475 \\
(11.498)\end{array}$ & $\begin{array}{c}0.610 \\
(2.702)\end{array}$ & $\begin{array}{c}1.611 \\
(43.901)\end{array}$ & $\begin{array}{c}0.486 \\
(28.539)\end{array}$ & $\begin{array}{c}1.454 \\
(14.331)\end{array}$ & $\begin{array}{c}0.503 \\
(136.657)\end{array}$ & $\begin{array}{c}1.434 \\
(149.853)\end{array}$ \\
\hline fantasy or sci-fi & $\begin{array}{l}0.363^{* * *} \\
(0.102)\end{array}$ & $\begin{array}{l}-0.133 \\
(0.123)\end{array}$ & $\begin{array}{c}0.377^{* * *} \\
(0.103)\end{array}$ & $\begin{array}{l}-0.143 \\
(0.129)\end{array}$ & $\begin{array}{l}0.361^{* * *} \\
(0.102)\end{array}$ & $\begin{array}{l}-0.125 \\
(0.123)\end{array}$ & $\begin{array}{c}0.349^{* * *} \\
(0.100)\end{array}$ & $\begin{array}{l}-0.167 \\
(0.122)\end{array}$ \\
\hline suspense or horror & $\begin{array}{l}0.252^{* * *} \\
(0.070)\end{array}$ & $\begin{array}{c}0.053 \\
(0.089)\end{array}$ & $\begin{array}{l}0.249^{* * *} \\
(0.071)\end{array}$ & $\begin{array}{c}0.033 \\
(0.086)\end{array}$ & $\begin{array}{l}0.250^{* * *} \\
(0.070)\end{array}$ & $\begin{array}{l}0.066 \\
(0.090)\end{array}$ & $\begin{array}{l}0.236^{* * *} \\
(0.069)\end{array}$ & $\begin{array}{c}0.021 \\
(0.091)\end{array}$ \\
\hline year & $\begin{array}{l}-0.046^{* * *} \\
(0.011)\end{array}$ & $\begin{array}{c}0.034 \\
(0.026)\end{array}$ & $\begin{array}{l}-0.043^{* * *} \\
(0.011)\end{array}$ & $\begin{array}{c}0.023 \\
(0.027)\end{array}$ & $\begin{array}{c}-0.047^{* * *} \\
(0.011)\end{array}$ & $\begin{array}{l}0.035 \\
(0.027)\end{array}$ & $\begin{array}{l}-0.047^{* * *} \\
(0.011)\end{array}$ & $\begin{array}{c}0.037 \\
(0.027)\end{array}$ \\
\hline $\mathrm{pg}$ & $\begin{array}{l}-0.036 \\
(0.130)\end{array}$ & $\begin{array}{l}-0.031 \\
(0.159)\end{array}$ & $\begin{array}{l}-0.033 \\
(0.105)\end{array}$ & $\begin{array}{l}-0.101 \\
(0.158)\end{array}$ & $\begin{array}{l}-0.036 \\
(0.129)\end{array}$ & $\begin{array}{l}-0.015 \\
(0.158)\end{array}$ & $\begin{array}{l}-0.041 \\
(0.131)\end{array}$ & $\begin{array}{c}0.018 \\
(0.158)\end{array}$ \\
\hline $\operatorname{pg} 13$ & $\begin{array}{l}0.029 \\
(0.127)\end{array}$ & $\begin{array}{c}0.203 \\
(0.162)\end{array}$ & $\begin{array}{l}0.007 \\
(0.095)\end{array}$ & $\begin{array}{c}0.141 \\
(0.163)\end{array}$ & $\begin{array}{l}0.029 \\
(0.126)\end{array}$ & $\begin{array}{l}0.230 \\
(0.161)\end{array}$ & $\begin{array}{c}0.012 \\
(0.128)\end{array}$ & $\begin{array}{c}0.235 \\
(0.161)\end{array}$ \\
\hline $\mathrm{r}$ & $\begin{array}{c}0.022 \\
(0.131)\end{array}$ & $\begin{array}{c}0.066 \\
(0.163)\end{array}$ & $\begin{array}{l}-0.019 \\
(0.098)\end{array}$ & $\begin{array}{l}0.017 \\
(0.158)\end{array}$ & $\begin{array}{c}0.022 \\
(0.130)\end{array}$ & $\begin{array}{c}0.090 \\
(0.162)\end{array}$ & $\begin{array}{l}0.010 \\
(0.131)\end{array}$ & $\begin{array}{c}0.095 \\
(0.161)\end{array}$ \\
\hline constant & $\begin{array}{l}-6.261^{\star \star \star *} \\
(0.705)\end{array}$ & $\begin{array}{l}-8.137^{\star \star \star} \\
(1.163)\end{array}$ & $\begin{array}{l}-6.508^{\star \star \star} \\
(0.629)\end{array}$ & $\begin{array}{c}-8.523^{\star \star \star} \\
(1.069)\end{array}$ & $\begin{array}{l}-6.324^{\star \star \star} \\
(0.693)\end{array}$ & $\begin{array}{l}-8.237^{\star \star \star} \\
(1.174)\end{array}$ & $\begin{array}{c}-6.311^{\star \star \star} \\
(0.702)\end{array}$ & $\begin{array}{c}-8.293^{\star \star \star} \\
(1.115)\end{array}$ \\
\hline $\begin{array}{l}\text { Average quality of cold- } \\
\text { opened movie }^{\text {a }}\end{array}$ & $\begin{array}{l}19.172^{* \star *} \\
(0.837)\end{array}$ & $\begin{array}{c}29.987^{\star * \star} \\
(1.252)\end{array}$ & $\begin{array}{l}45.667^{* * *} \\
(0.772)\end{array}$ & $\begin{array}{l}38.815^{* \star *} \\
(1.117)\end{array}$ & $\begin{array}{l}19.185^{* * *} \\
(0.839)\end{array}$ & $\begin{array}{c}27.159^{* * *} \\
(1.615)\end{array}$ & $\begin{array}{c}19.023^{* * *} \\
(0.805)\end{array}$ & $\begin{array}{c}26.205^{* \star *} \\
(1.623)\end{array}$ \\
\hline $\begin{array}{l}\text { Predicted cold-opening } \\
\text { percentage }^{b}\end{array}$ & $\begin{array}{l}0.108^{\star \star \star} \\
(0.006)\end{array}$ & $\begin{array}{c}0.179^{\star \star \star} \\
(0.013)\end{array}$ & $\begin{array}{c}0.501^{\star \star \star} \\
(0.395)\end{array}$ & $\begin{array}{c}0.498^{\star \star \star} \\
(0.002)\end{array}$ & $\begin{array}{c}0.108^{\star \star \star} \\
(0.006)\end{array}$ & $\begin{array}{c}0.196^{\star \star \star} \\
(0.017)\end{array}$ & $\begin{array}{c}0.107^{\star \star \star} \\
(0.005)\end{array}$ & $\begin{array}{l}0.182^{\star \star \star} \\
(0.017)\end{array}$ \\
\hline Predicted cold premium ${ }^{\mathrm{C}}$ & $\begin{array}{c}-0.101^{\star \star \star \star} \\
(0.014)\end{array}$ & $\begin{array}{c}-0.075^{\star \star \star} \\
(0.007)\end{array}$ & $\begin{array}{c}0.001^{\star \star \star \star} \\
(0.000)\end{array}$ & $\begin{array}{l}0.001^{\star \star \star} \\
(0.000)\end{array}$ & $\begin{array}{c}-0.102^{\star \star \star} \\
(0.014)\end{array}$ & $\begin{array}{c}-0.054^{\star \star \star} \\
(0.015)\end{array}$ & $\begin{array}{c}0.105 \\
(0.103)\end{array}$ & $\begin{array}{l}0.177^{\star \star \star} \\
(0.040)\end{array}$ \\
\hline observations & 778 & 525 & 778 & 525 & 778 & 525 & 778 & 525 \\
\hline log likelihood & -755.19 & -676.61 & -1150.13 & -821.48 & -755.20 & -673.79 & -752.49 & -664.08 \\
\hline
\end{tabular}

* Significant at the $10 \%$ level

** Significant at the $5 \%$ level

*** Significant at the $1 \%$ level

Table A.7: Parameter estimates for jointly estimated baseline, baseline with correct Bayesian expectations, baseline with free $E_{m}\left(q_{j} \mid 1\right)$ parameter, and cognitive hierarchy models by time period, using weekend box office revenue and cold-opening decisions data. Standard errors are calculated from 100 bootstraps for each model and time period.

a. Actual values: $13.47,24.49$. b. Actual values: $0.055,0.181$. c. Actual values: 0.059, 0.301 